\title{
Concorrência e energia eólica
}

\author{
Conselho Administrativo de Defesa Econômica (Cade)
}

\section{Ato de Concentração no 08012.009044/2011-39}

Requerentes: Rio Bravo Energia I - Fundo de investimento em Participações e Servtec Investimentos e Participações Ltda.

Advogados: Barbara Rosenberg, Rafael Szmid, José Inácio Ferraz de Almeida Prado Filho, e outros.

Relator: Conselheiro Alessandro Octaviani Luis

EMENTA: Ato de Concentração - Operação realizada no Brasil Procedimento Sumário: Portaria SEAE/SDE 01/2003, art. 6o, inc. X Aquisição, por parte do Fundo Rio Bravo, de participação equivalente a 50\% do capital social de SPE a ser constituída para a implantação, desenvolvimento e operação de projeto de geração eólica, sendo os restantes 50\% detidos pela Servtec - Procedimento Sumário - Hipótese de subsunção da Lei 8.884/94, art. 54, §3: Faturamento superior a $\mathrm{R} \$ 400.000 .000,00$ - Apresentação tempestiva - Mercado de geração de energia elétrica - Ocorrência de sobreposição horizontal - Ausência de integração vertical - Parecer SEAE/SDE favorável - Parecer PROCADE Favorável - Aprovação sem restrições

Palavras-chave: Sistema Financeiro - Fundos de Investimento - Conhecimento - Competências compartilhadas CADE e CVM 


\section{Voto}

(Versão Pública)

\section{Das Requerentes}

1. Rio Bravo Energia I - Fundo de Investimento em Participações ("Fundo Rio Bravo") é fundo de investimento em participação que tem por objetivo o investimento em projetos de transmissão e de geração de energia elétrica, sobretudo em energias renováveis.

2. Servtec Investimentos e Participações Ltda. ("Servtec") é sociedade holding que desenvolve projetos na área de geração de energia elétrica. Pertencente ao grupo brasileiro Servtec.

3. Pelo menos um dos grupos apresentou faturamento superior a $\mathrm{R} \$ 400$ milhões.

\section{Da Operação}

4. Trata a operação da aquisição, por parte do Fundo Rio Bravo, de participação equivalente a $50 \%$ do capital social e votante de SPE a ser constituída para a implantação, desenvolvimento e operação do projeto de geração eólica denominado CGE Malhadinha I. ${ }^{1}$ Os outros $50 \%$ da SPE serão detidos pela Servtec.

5. A aquisição de participação por parte do Fundo Rio Bravo se dará, alternativamente: (i) por meio da subscrição e integralização de debêntures conversíveis, com posterior conversão desses títulos em ações de emissão da SPE; ou (ii) por meio da subscrição e integralização de ações ordinárias de emissão da SPE.

1 Para fins da implantação e da exploração do projeto, será criada uma SPE (i) para a qual todos os ativos, direitos e licenças relacionados à CGE Malhadinha I serão transferidos, e (ii) que receberá as outorgas para a produção e venda da energia adjudicadas no Leilão. A CGE Malhadinha I foi cadastrada na Empresa de Pesquisa Energética - EPE para participar do Leilão A-3/Reserva de 2011. A inscrição no Leilão foi feita em nome do consórcio constituído pela Servtec com duas de suas sociedades controladas (Servtec Energia Ltda. e Servtec RM Participações S.A.). 


\section{Do Conhecimento}

6. As requerentes formularam pleito de não conhecimento da operação, uma vez que o Fundo Rio Bravo (i) teria suas quotas bastante pulverizadas e (ii) ser gerido e administrado de forma independente de seus quotistas (fls. 223). Tais razões encontrar-se-iam lastreadas em jurisprudência deste Conselho, sobretudo em metodologia desenvolvida e apresentada pelo i. conselheiro Olavo Chinaglia, acerca dos critérios para conhecimento de atos de concentração envolvendo fundos de investimento.

7. A Procade, em seu parecer, é contundente quanto à necessidade de conhecimento da presente operação (fls. 267 e ss.): “Como o conhecimento de operações envolvendo fundos tem sido constantemente questionado perante o Conselho, cumpre tecer uma análise mais acurada sobre o assunto. Antes, é interessante observar que a participação de FIP's em operações realizadas pelo SBDC se faz cada vez mais crescente. Observe-se, ainda, que em 2007, os fundos de private equity estiveram presentes em 15,3\% dos negócios realizados no Brasil, havendo um crescimento de $72 \%$ de participação em relação ao ano anterior, notando-se, ainda, que, de 2005 para 2006, esse crescimento foi de $146 \%$. Por outro lado, segundo estudos realizados no mercado de private equity, o setor que deve receber mais investimentos é o de infraestrutura, com $24 \%$ da preferência e, em seguida, está o setor de energia (eletricidade, petróleo e gás). No que concerne à análise de operações envolvendo FIP's, inicialmente, importa salientar que o caput e o par. 3o do art. 54 da Lei 8884/94 não se referem a todos os atos e negócios jurídicos celebrados por empresas, mas sim aos atos ou negócios jurídicos que levem à concentração, em mãos de uma empresa ou de um grupo de empresas, do poder econômico de duas ou mais empresas antes independentes. Apenas tais atos são aptos a gerar efeitos que 'possam limitar ou de qualquer forma prejudicar a livre concorrência, ou resultar na dominação de mercados relevantes de bens e serviços', ou seja, todos os atos ou negócios jurídicos que levem à concentração, em mãos de uma empresa ou de um grupo de empresas, do poder econômico de duas ou mais empresas antes independentes. Nesse contexto, se questiona se determinadas aquisições de participações em empresas, realizadas por Fundos de Investimento em Participações - FIP's (ou fundo de private equity), como no presente caso, têm aptidão de, na prática, integrar o seu poder econômico, considerando-se que 'a concentração econômica' a que se refere o art. 54, acima referido, é a concentração do poder econômico de duas ou mais empresas antes independentes. (...) (a interferência do fundo na 
sociedade alvo dos investimentos) pode-se apresentar desnecessária, vez que é da própria natureza dos FIP's a participação no processo decisório da companhia investida, consoante a regulamentação que lhe é própria, a Instrução CVM n. 391/2003, que assim define tais fundos no seu art. 2o: 'O Fundo de Investimento em Participações (fundo), constituído sob a forma de condomínio fechado, é uma comunhão de recursos destinados à aquisição de ações, debêntures, bônus de subscrição, ou outros títulos e valores mobiliários conversíveis ou permutáveis em ações de emissão de companhias, abertas ou fechadas, participando do processo decisório da companhia investida, com efetiva influência na definição de sua política estratégica e na sua gestão, notadamente através da indicação de membros do Conselho de Administração.' Assim, levando-se em conta o fato de que tais fundos são constituídos para participarem no processo decisório da companhia investida, de acordo com o entendimento consagrado nos votos referidos, as operações realizadas por FIP's devem sempre ser conhecidas pelo Cade (...). No que concerne à aquisição de participações societárias envolvendo FIP's, há de se transportar para a sua análise o cuidado do Conselho com os efeitos concorrenciais gerados em operações que abranjam participações minoritárias. Como já exposto, as participações minoritárias dos FIP's em empresas rivais (daquelas empresas em que o fundo já detém participação), ainda que passivas, podem, em certos casos, gerar efeitos anticompetitivos na medida em que diminuam os incentivos do fundo, por meio de suas empresas rivais, em competir com a empresa alvo concorrente (efeitos unilaterais) e facilitem arranjos colusivos entre esses rivais (efeitos coordenados). Nesse passo, deve-se, como em qualquer outro ato de concentração, proceder ao exame da operação e do mercado relevante envolvido, atentando-se para as peculiaridades do caso. Por outro lado, a própria análise de tais efeitos já apresenta uma análise do mérito da operação que termina por transpor a questão do conhecimento ou não da operação. Desse modo, entende-se que deve haver o conhecimento da operação, ainda que não haja ingerência dos cotistas sobre as estratégias de investimento dos recursos do fundo e pelo fundo nas empresas alvo do investimento. Além do mais, cumpre analisar, também, se a empresa gestora/administradora do fundo apresenta-se independente ou se possui vínculo de fato ou de direito com os cotistas do fundo, fazendo parte do mesmo grupo. A existência de uma relação como tal termina por estender eventual influência dos cotistas sobre o fundo, ainda que o seu regulamento afaste esse tipo de interferência. Por fim, não se deve ignorar a possibilidade da gestora/administradora do fundo possuir em sua carteira 
de clientes uma gama de fundos que investem no mesmo mercado relevante e cujas empresas investidas deveriam ser supostamente concorrentes. Obviamente, a concentração da gestão termina por unificar as estratégias de investimentos, revelando efeitos coordenados. (...) Em razão do faturamento do Grupo Servtec, o conhecimento da presente operação é medida que se impõe. Todavia, o fundo requerente sustenta que a presente operação poderia ser dispensada de notificação, pois se trata, fundamentalmente, de aporte efetivado por investidor financeiro e que não há interferência dos cotistas na administração do fundo e nem desse na administração da empresa-alvo. À vista das alegações do requerente, cumpre demonstrar, no presente tópico, que a presente operação não se trata de mero investimento do fundo e da Servtec na empresa-alvo. (...) Consoante o Acordo de Investimento referido, o Fundo Rio Bravo, mediante o cumprimento de determinadas condições, tem o interesse de investir no empreendimento elétrico, seja: (i) por meio da subscrição e integralização de debêntures conversíveis de emissão da SPE; ou (ii) através da subscrição e integralização de ações ordinárias de emissão da SPE em quantidade que assegure ao FIP participação equivalente a $50 \%$ no capital social da SPE. Quanto à verificação da intervenção do fundo sobre as decisões estratégicas da sociedade-alvo dos investimentos, convém verificar o regulamento do fundo [CONFIDENCIAL]. Assim, resta claro que o fundo requerente interfere na administração das companhias-alvo dos seus investimentos. Por isso, convém também perceber que, no presente caso, os cotistas participam das decisões estratégicas de investimento do fundo. Verifica-se que a Assembleia-Geral de Cotistas participa do processo decisório do fundo. Observe-se que o regulamento do fundo, no Capítulo XIV, item 14.1, inciso X, estabelece que [CONFIDENCIAL]".

8. Pelo exposto, quer (i) pela condição imposta pela regulação setorial da CVM para o Fundo requerente, de que interfira ativamente na gestão dos ativos, ou (ii) pela análise concreta e detalhada de sua distribuição jurídica de poderes, não restam dúvidas sobre a pertinência da posição final, pelo conhecimento da presente operação, adotada pela Procade em seu extenso e minucioso parecer.

9. Assim, (i) pela mera aplicação do critério de faturamento estabelecido na Lei $n^{\circ} 8.884 / 94$, art. 54, $\S 3$, (ii) considerando que se trata de fundo de private, que efetivamente participa do processo decisório das empresas-alvo, e (iii) pela análise do caso concreto; conheço da operação.

10. Entretanto, tendo em vista que a discussão sobre o conhecimento ou não de operações envolvendo fundos de investimento tem sido objeto 
de preocupações do Conselho e é, certamente, um dos pontos relevantes de uma adequada política de concorrência global para o setor, adiante farei uma análise razoavelmente detida sobre alguns dos votos que constituíram o terreno sobre o qual tal discussão vem se alicerçando.

11. É claro, como se verá, que uma política concorrencial para os fundos de investimento transcende em muito a mera questão dos critérios para conhecimento das operações em que figuram como compradores/vendedores.

12. Entretanto, tal questão reveste-se de importância razoável, principalmente por ter tecido, nos anos recentes, um espaço de aprendizado - mais ou menos adequado, mais ou menos consciente - sobre quais os principais pontos a serem observados daqui para diante, em um cenário no qual a economia dos fundos de investimento está mais fortalecida do que em qualquer outra etapa da história do país, podendo cumprir seu importante papel de irrigação e democratização do crédito para os empreendedores - sendo, inclusive, um canal alternativo aos bancos, privados e públicos - , mas, também, trazendo desafios ao ambiente concorrencial saudável.

\section{Tempestividade}

13. As requerentes apresentaram como ato vinculativo inicial da operação o "Acordo de Investimentos e Outras Avenças", de 17 de agosto de 2011. O ato foi apresentado às autoridades de defesa da concorrência em 6 de setembro de 2011. Constata-se, pois, a tempestividade da notificação.

14. Taxa processual devidamente recolhida.

\section{Da Análise}

\section{A. Mercados financeiros e mercado de capitais: premissas para a regulação}

15. A presente análise, em contexto mais amplo, insere-se na interseção que a autoridade de concorrência realiza com as autoridades competentes para regular os mercados financeiros como um todo. Os mercados financeiros, como se sabe, estruturam-se pela divisão funcional - embora muitas vezes altamente interligadas - de diversos mercados, como o de crédito, o monetário, o cambial e o de capitais.

16. O mercado de crédito caracteriza-se pela "intermediação financeira"; a transferência de recursos entre agentes conta, via de regra, com a participação 
de uma instituição financeira, estabelecendo-se a relação jurídica entre a instituição financeira e o aplicador, ou entre a instituição financeira e o tomador de recursos; sendo a instituição financeira sempre parte do negócio jurídico, a transferência de recursos, entre agentes, ocorre de forma indireta. O mercado monetário ou mercado aberto ("open market") é mecanismo de política monetária, através do qual as autoridades agem sobre os níveis desejados ou não de liquidez da economia - adquirindo e desfazendo-se de títulos públicos ou títulos privados da sua própria carteira; busca possibilitar o ajuste de saldos de reservas das instituições financeiras e a financiar ocasionais desencaixes do Tesouro. O mercado cambial é o lócus de operações que envolvem a conversão de moedas estrangeiras em moeda nacional ou o inverso, com a intermediação de instituições financeiras autorizadas, influenciando o mercado monetário em razão dos efeitos sobre os saldos de reservas bancárias das instituições financeiras. Por fim, o mercado de capitais é o espaço para realização de transações com o fim de suprir necessidades de capital das empresas, onde os recursos são captados do público investidor, por meio da emissão de títulos ou valores mobiliários, ${ }^{2}$ negociados nos mercados

2 Pode-se investigar o tipo "valores mobiliários" por vários critérios: as definições legais, jurisprudenciais - judiciais ou administrativas - , doutrinárias, em direito nacional ou comparado. Preliminarmente, valores mobiliários são direitos negociados em massa no mercado de capitais, coagulados ou não em documento formal, que tem o condão de representar interesse ou participação em propriedade ou patrimônio, possuindo como característica econômica servirem como meio de inversão financeira, com alta liquidez e ágil negociabilidade. A definição legal aparece pela primeira vez em nosso ordenamento na Lei 6.385/76, de criação da Comissão de Valores Mobiliários, em seu artigo 2o: "São valores mobiliários sujeitos ao regime desta Lei: I - as ações, partes beneficiárias e debentures, os cupões desses títulos e os bônus de subscrição; II - os certificados de depósito de valores mobiliários; III - outros títulos criados ou emitidos pelas sociedades anônimas, a critério do Conselho Monetário Nacional". Uma sinuosa caminhada tem levado a sucessivas inclusões, como a ocorrida através da Lei 10.303/2001, tendo como determinação a inclusão dos "derivativos" como "valor mobiliário", nos seguintes termos: "São valores mobiliários sujeitos ao regime desta Lei: I - as ações, debentures e bônus de subscrição; II - os cupons, direitos, recibos de subscrição e certificados de desdobramento relativos aos valores mobiliários referidos no inciso I; III - os certificados de depósito de valores mobiliários; IV - as cédulas de debentures; $\mathrm{V}$ - as cotas de fundos de investimento em valores mobiliários ou de clubes de investimento em quaisquer ativos; VI - as notas comerciais; VII - os contratos futuros, de opções e outros derivativos, cujos ativos subjacentes sejam valores mobiliários; VIII - outros contratos derivativos, independentemente dos ativos subjacentes; IX - quando ofertados publicamente, quaisquer outros títulos ou contratos de investimento coletivo, que gerem direito de participação, de parceria ou de remuneração, inclusive resultante de prestação de serviços, cujos rendimentos advém do esforço do empreendedor ou de terceiros". A definição do que seja "valor mobiliário" e suas consequências, como se vê, é aberta, cabendo às autoridades um largo papel em sua definição, aproximando, por mais um ângulo, essa forma de atuação jurídica do Estado na economia da atuação em defesa da concorrência como um todo, notadamente marcada pela preocupação com os efeitos, de cunho notadamente 
de bolsa ou de balcão, o que o faz ser apreendido também como "mercado de títulos ou valores mobiliários" ou "mercado de valores mobiliários". ${ }^{3}$

17. Tais mercados são, preferencial e discursivamente, separados e autônomos. Para tanto, são erigidas algumas salvaguardas, como (i) a existência de pessoas jurídicas distintas, ainda que integrantes do mesmo conglomerado econômico, com (ii) patrimônio segregado para a realização de atividades submetidas a distintas categorias e intensidades de risco, e (iii) a submissão à fiscalização e controle por diferentes e especializados órgãos de polícia econômica.

18. No entanto, as linhas de interligação e conexão entre as operações são muito mais sensíveis do que permite supor uma ingênua crença, de origem formalista, na força das formas jurídicas. A teoria da economia informacional construiu ao longo do século XX um enorme aparato conceitual para apreender a força da transmissão da informação e seu poder conformador de comportamentos, preços e, por fim, realização material de poder econômico.

19. Por outro lado, de maneira muito mais dramática do que uma coleção de teorias que tentam afirmar o mundo empírico sobre o mundo das formas e hipóteses abstratas, a crise mundial de 2008 trouxe com todas as letras o ensinamento de que as atividades nos mercados financeiros vão se ligando e se referenciando em um amontoado de expectativas - supostamente racionais - que transcendem em muito a sapiência dos reguladores e dos regulados, construindo um mundo no qual a busca e pressão pelos resultados deixam, constantemente, de lado as determinações legais e contratuais.

20. Por isso, é claro, qualquer regulação sobre qualquer manifestação dos mercados financeiros deve ter em conta que sua realidade é dinâmica e não estática, que sua estrutura encontra-se nos resultados e efeitos e não nos discursos, que se deve conhecer as articulações e não ficar ilusoriamente detido em partes isoladas. Essas são as premissas para uma regulação que, simultaneamente,

funcional e dinâmico. Para exposições detalhadas do conceito de "valor mobiliário": DIAS, Luciana. Regulação e autorregulação no mercado de valores mobiliários, p. 21-38. Dissertação apresentada na Faculdade de Direito da USP, 2005. MOTTA, Rita. O conceito de valor mobiliário no direito brasileiro, p. 59-110. Dissertação de Mestrado, Faculdade de Direito da USP, 2002.

3 Para uma exposição mais detalhada - e que distingue as expressões "mercado de capitais" e "mercado de valores mobiliários", cf. DIAS, Luciana. Regulação e autorregulação no mercado de valores mobiliários, op. cit., p. 21: “(...) as expressões 'mercado de valores mobiliários' e'mercado de capitais' não serão sinônimas. Mercado de valores mobiliários será um segmento específico do Mercado de capitais, destinado à negociação pública (i.e., com apelo à poupança popular) de valores mobiliários. Como parece óbvio, o Mercado de valores mobiliários é aquele no qual são negociados os valores mobiliários". Em sentido diverso, tomando as duas expressões por sinônimos, cf. MOTTA, Rita. O conceito de valor mobiliário no direito brasileiro, op. cit., p. 25-26. 
apreenda os benefícios advindos de tais mercados e empreenda barreiras contra as estruturas e condutas que podem desorganizar o funcionamento adequado da economia.

21. Aliás, é com base nessas premissas que o Bacen recentemente promulgou regra administrativa que tenta organizar, de maneira mais adequada e nos limites de sua competência vertida à preocupação com higidez sistêmica, análise de concentrações nas quais os bancos participem, por intermédio da Resolução no. 4.062, de 29 de março de 2012, que "estabelece normas, condições e procedimentos para a instalação de dependências no exterior, e para a participação societária direta ou indireta, no País e no exterior, por parte de instituições financeiras e demais instituições autorizadas a funcionar pelo Banco Central do Brasil". ${ }^{4}$

22. A imprensa econômica captou essa preocupação do Banco Central com as articulações, resultados e dinâmicas (e não partes isoladas, discursos e estática), da seguinte maneira: "Banco terá de pedir aval do BC para comprar empresa. Regulação - Objetivo é reduzir riscos de instituição atuar em outra área. A partir de hoje, todos os bancos terão que pedir uma autorização prévia ao Banco Central do Brasil (BC) para comprar, de forma direta ou indireta, uma empresa de outro segmento no país ou no exterior. Antes, a autoridade monetária exigia apenas a comunicação do negócio. A medida foi aprovada,

4 “Art. 1으 $\mathrm{O}$ art. 8ㅇ da Resolução no 2.723, de 31 de maio de 2000, passa a vigorar com a seguinte redação: 'Art. $8^{\circ}$ Depende de prévia autorização do Banco Central do Brasil a participação de instituições financeiras e demais instituições autorizadas por aquela Autarquia, de forma direta ou indireta, no capital de quaisquer sociedades sediadas no País ou no exterior, excetuadas as participações societárias típicas de carteiras de investimento mantidas por bancos de investimento, bancos de desenvolvimento, agências de fomento e por bancos múltiplos com carteira de investimento ou de desenvolvimento. $\S 1$ 1 A prévia autorização prevista no caput aplica-se à participação, ao aumento percentual da participação e às situações para as quais é exigida a elaboração de demonstrações financeiras de forma consolidada, nos termos do art. 3ำ, não enquadradas nas condições estabelecidas no $\S 4^{\circ}$. $\S 2^{\circ}$ - Somente serão admitidas participações em empresas que exerçam atividades complementares ou subsidiárias às da instituição participante. $\S 3^{\circ}$ Os pedidos de autorização para participação societária e para aumento percentual de participação devem ser instruídos com informações e justificativas circunstanciadas que contemplem, no mínimo, a descrição do objeto social e das atividades da sociedade participada, a análise da sinergia decorrente da participação e a adequação da participação acionária à estratégia de negócios da instituição participante. $\S 4^{\circ} \mathrm{O}$ disposto no caput não se aplica às participações societárias no País, de caráter temporário, não registradas no ativo permanente e não consolidadas na forma da regulamentação em vigor. § 5 ${ }^{\circ} \mathrm{O}$ Banco Central do Brasil poderá: I - determinar, a qualquer tempo, às instituições financeiras, com relação a participações societárias de sua titularidade, a apresentação das informações e justificativas de que trata o $\S 3^{\circ}$, bem como a implementação de medidas de ajuste consideradas cabíveis; e II - estabelecer as condições para a remessa das informações e justificativas de que trata o $\S 3$." 
ontem, em reunião do Conselho Monetário Nacional. Segundo o chefe do departamento de normas do BC, Sérgio Odilon, a regra tem o objetivo de dar mais segurança ao sistema financeiro, reduzindo os riscos sistêmicos, que podem ser ampliados quando um banco, que tem como atividade fim a intermediação financeira, passa a atuar em outro segmento. 'O princípio do banco é fazer intermediação financeira. Se quer participar do que não é típico do business, deverá consultar o órgão regulador', explicou." (Valor Econômico, 30 mar. 2012, C3). Ou, ainda: “BC poderá barrar compra de empresas por bancos. Nova regra aprovada pelo CMN cria obrigatoriedade de autorização do Banco Central na aquisição de empresas não financeiras por bancos. Os bancos que quiserem comprar empresas não financeiras terão agora que pedir autorização prévia ao Banco Central. Dessa forma, o governo poderá barrar aquisições que comprometam a saúde financeira dessas instituições. Antes, o Banco Central só analisava previamente aquisições que envolvessem duas empresas financeiras. Para comprar uma construtora, por exemplo, não era necessário pedir autorização, bastava comunicar a autoridade monetária sobre o negócio. (...) As novas regras seguem recomendações internacionais de transparência e contribuem, segundo o Banco Central, para a avaliação dos riscos assumidos nessas operações. 'O BC vai avaliar se há alguma 'externalidade negativa' que pode ser levada para dentro do banco', afirmou o chefe de departamento do Banco Central" (O Estado de S. Paulo, 30 mar. 2012, B5).

23. Uma regulação com essas premissas (centrada na dinâmica e não na estática, nos efeitos e resultados e não nos discursos ou formas jurídicas, e capaz de apreender as articulações e não parar sua análise nas partes isoladas do sistema) deve estar presente na análise dos fundos de investimento e suas questões concorrencialmente sensíveis. É para colaborar com essa construção institucional que trago algumas reflexões para análise desse i. Conselho Administrativo de Defesa Econômica.

\section{B. Mercado de capitais e fundos de investimento}

24. Como destaca o "Novo Plano Diretor do Mercado de Capitais Enfrentando com Maturidade os Desafios da Crise", este mercado possui a "(...) missão de mobilizar a poupança e financiar o desenvolvimento da economia nacional". Tal vem acontecendo ao longo dos últimos anos, como destacado no documento, na seguinte proporção: “O aumento de

5 ROCCA, Carlos (Org.). O novo plano diretor do mercado de capitais: enfrentando com maturidade os desafios da crise. Rio de Janeiro: Campus; Elsevier; Ibmec, 2009. p. 8. 
sua participação na mobilização de poupanças foi acompanhado por forte crescimento da base de investidores institucionais - fundos de pensão, planos de previdência abertas, fundos de investimento e companhias de seguros - , além de considerável captação de recursos de investidores estrangeiros. A melhoria de desempenho no financiamento da economia foi ainda mais expressiva, traduzida no aumento de emissões primárias de ações e dívida, caracterizada também por um grande número de empresas que abriram seu capital. Entre 2002 e setembro de 2008, o volume total de emissões de ações e dívida atingiu o valor de $\mathrm{R} \$ 540$ bilhões, dos quais $\mathrm{R} \$ 250$ bilhões apenas em emissões primárias". ${ }^{6}$

\section{As "ideias capitais" para os fundos de investimento}

25. Nas últimas décadas, o mercado financeiro, de maneira geral, e o mercado de capitais, de maneira particular, foi fortemente modelado pelo que a literatura denominou "ideias capitais", a partir da contribuição ela própria plenamente alinhada com tal movimento de ideias - de Peter Bernstein. Segundo sua reconstrução da "História do Mercado de Capitais", "o fardo de ideias, modelos, conceitos e sistemas incorporados na estrutura teórica das finanças modernas - o que eu chamo de Ideias Capitais - se constituiu-se entre 1952 e 1973. Esses conceitos pouco devem a Keynes e quase tudo a Marshall. Toda estrutura subjacente das Ideias Capitais se escora numa premissa sobrejacente: os investidores não têm dificuldades em fazer escolhas ótimas em meio ao emaranhado estonteante de fatos, rumores,

6 Ibid., p. 27. Entre diversas externalidades positivas desse desenvolvimento, pode-se citar, inclusive, a capacidade de impulsionamento dos investimentos e revitalização da praça de negócios do Rio de Janeiro, como noticiado pelo jornal O Estado de S. Paulo, em 19 de maio de 2012, B23: "Rio Investors Day terá presença de 70 fundos estrangeiros - Grupos internacionais responsáveis pela gestão de trilhões de dólares em ativos desembarcam no Rio de Janeiro na próxima semana para o Rio Investors Day (RID), nos dias 21 e 22. Pesos pesados como o americano BlackRock (que sozinho movimenta US\$3,684 trilhões), Aberdeen, Artisan Partners, GIC (do governo de Cingapura) e o russo NHC Capital são alguns dos 70 estrangeiros que estarão presentes. É o triplo do ano passado, primeira edição do evento, que tem como foco incluir a capital carioca no calendário financeiro global. (...) A expectativa é que os grandes eventos esportivos a serem sediados no Rio e os planos dessas empresas, em especial a Petrobras, tenham um efeito catalisador na carteira de negócios da cidade. Isso inclui a revitalização do setor financeiro carioca, esvaziado desde o fechamento da Bolsa de Valores do Rio, há mais de uma década. (...) A estratégia é ser um polo complementar a São Paulo, e não competir com a capital paulista, centro financeiro do país. (...) O processo de atração de investidores parece já ter sido iniciado. A californiana Pimco, maior gestora de recursos de renda fixa do mundo, que administra US\$1,77 trilhão, anunciou a abertura de um escritório no Rio em setembro. Será a base para suas operações na América Latina. Outra que montou escritório na cidade foi a HIG Capital, que tem US\$ 8 bilhões sob gestão em fundos". 
descontinuidades, evasivas e incertezas que compõem o mundo real ao nosso redor. Com o tempo, essa tensão entre o conceito ideal de racionalidade humana e a dura realidade de nossa vida cotidiana se transformou em questão cada vez mais contenciosa. O quanto sabemos sobre como as pessoas do mundo real tomam decisões e fazem escolhas? Qual é a magnitude das diferenças entre as premissas teóricas e o mundo real? E será que essas diferenças são importantes? Embora tais questões sempre tenham sido fundamentais para a compreensão da maneira como os investidores se comportam e como suas respostas afetam o desempenho dos mercados financeiros, ninguém empreendeu nenhum esforço sistemático para fornecer respostas até meados da década de 1960". ${ }^{7}$

26. Esse conjunto de ideias, que permitiram uma fortíssima ligação da academia norte-americana com os agentes do mercado financeiro e, finalmente, levaram à própria reestruturação desses, a partir da criação de modelos de hiper-racionalidade e potentes softwares que faziam tais modelos girarem, tem como núcleo organizativo "a predominância de considerações sobre o risco nas decisões, a precificação de ativos em mercados competitivos, o poder da diversificação, os enormes obstáculos às tentativas de superar os mercados e o gigantesco passo à frente que consistiu no desenvolvimento do modelo de precificação de opções. Em suma, o termo Ideias Capitais refere-se ao trabalho de Harry Markowitz sobre seleção de portfolios, às visões revolucionárias de Franco Modigliani e de Merton Miller sobre finanças empresariais e sobre o comportamento dos mercados, ao Modelo de Precificação de Ativos Financeiros, de Sherp-Treynor-Mossin-Lintner, à explicação de Engene Fama sobre a Hipótese de Mercado Eficiente e ao modelo de precificação de opções de Fischer Black, Myron Scholes e Robert C. Merton". ${ }^{8}$

27. Tal conjunto de ideias veio a permitir uma gigantesca variedade de instrumentos de crédito, potencializando o efeito "máquina do tempo" embutido nos mercados financeiros, como reconta Bernstein: "Instintivamente, pensamos nos mercados financeiros como centros em que os compradores procuram ativos subavaliados e os vendedores descartam o que consideram superavaliado - em outras palavras, onde raramente os preços estão 'certos'. Mas a busca por valor, ou por alfa, é apenas parte do que ocorre nos mercados financeiros, e não raro apenas pequena parte. As transações nesses mercados são muito variáveis quanto a seus objetivos, porque os mercados

\footnotetext{
7 BERNSTEIN,Peter. A história do mercado de capitais: o impacto da ciência e tecnologia nos investimentos. Tradução de Afonso Serra. Rio de Janeiro: Elsevier, 2008. p. 4.

8 Ibid., nota.
} 
financeiros são lugares onde os proprietários podem converter seus ativos em dinheiro e onde os detentores de liquidez conseguem encontrar aplicações para o dinheiro. Nessa função, os investidores que usam caixa para comprar recursos capazes de gerar fluxos de caixa futuros oferecem aos vendedores desses ativos a opção de realizar no presente o valor descontado dessa capacidade de geração de caixa ao longo do tempo. Porém, também ocorre algo mais profundo. Ao exercerem esse papel, os mercados financeiros são como máquinas do tempo que permitem aos vendedores comprimir o futuro no presente e aos compradores estender o presente no futuro. Sem os mercados financeiros, todos os ativos seriam do tipo comprar e manter, ao mesmo tempo em que o custo de capital seria mais alto do que é hoje". ${ }^{9}$ As ideias capitais "sobre avaliação, sobre as aplicações praticamente ilimitadas de derivativos e sobre o significado da volatilidade impregnaram todos os mercados e todos os ativos no mundo inteiro" ${ }^{10}$ Em 2008, as consequências práticas de tais ideias também se tornavam mais visíveis.

\section{Atuação do Estado $N A$ e $S O B R E$ a economia dos fundos de investimento}

28. Essa realidade econômica, no Brasil (país marcado pela condição do subdesenvolvimento, no qual o Estado teve e tem um papel de enorme

9 Ibid., p. 25. Às p. 29-30, o autor aponta limites às hipóteses de hiper-racionalidade neoclássica, embutidas em muitas das ideias subjacentes ao campo: “Com palavras seguras, Stephen Ross, um dos acadêmicos mais renomados de Ideias Capitais, descreveu o impacto da não arbitragem sobre o debate: 'Eu mesmo nunca achei que as pessoas - aí me incluindo - fossem tão racionais em seu comportamento. Ao contrário, sempre me surpreendo com suas atitudes. Mas esse nunca foi o aspecto central da teoria das finanças. A ausência de arbitragem exige que haja investidores ricos e inteligentes para fechar as oportunidades de arbitragem assim que aparecem - A teoria neoclássica é uma teoria de tubarões, não uma teoria do homo economicus racional, e essa é a principal diferença entre finanças e economia tradicional... Os arbitradores bem financiados identificam essas oportunidades [resultantes de erros comportamentais], atuam sobre elas e, com suas iniciativas, fecham esses diferenciais de preços aberrantes [ênfase nossa]'. Andrei Shleifer, economista de Harvard, e Robert Vishny, um dos colegas de Thaler, em Chicago, atacaram a posição de Ross num trabalho influente intitulado 'The Limits to Arbitrage'. Shleifer e Vishny desenvolveram sua argumentação com base na descrição das diferenças entre o mundo dos livros-texto e o mundo em que os investidores de carne e osso tomam suas decisões: 'A arbitragem dos livros-texto nos mercados financeiros não exige capital e não envolve risco. Na realidade, quase toda arbitragem exige capital e é tipicamente arriscada. Além disso, a arbitragem profissional é realizada por relativamente poucos investidores altamente especializados que usam recursos de terceiros. Essa arbitragem profissional tem várias implicações interessantes para a formação dos preços dos títulos mobiliários, inclusive a possibilidade de que a arbitragem se torne ineficaz em circunstâncias extremas, quando os preços apresentam divergências em relação aos valores fundamentais. $\mathrm{O}$ modelo também sugere onde é provável que apareçam anomalias nos mercados financeiros e por que a arbitragem não as elimina.' Em suma, o mundo real não é tão simples quando a descreve a Hipótese do Mercado Eficiente ou a argumentação de Ross".

10 Ibid., nota. 
relevância na formatação das estruturas econômicas mais significativas), submete-se às técnicas constitucionais de atuação do Estado em relação ao domínio econômico, como não poderia deixar de ser. Como tive a oportunidade de ressaltar em votos anteriores a respeito do sistema financeiro, a atuação do Estado em relação ao domínio econômico se estrutura a partir das categorias de (i) atuação no domínio econômico, como produtor, por (ia) absorção ou (ib) participação, e (ii) atuação sobre o domínio econômico, como agente normativo, por (iia) direção ou (iib) indução. ${ }^{11}$

29. No caso da economia dos fundos de investimento, essa categorização pode ser vista pela atuação do Banco Nacional de Desenvolvimento Econômico - BNDES, que realiza a atuação direta, como detentor de fundos de investimento, marcando a atuação do Estado no domínio econômico por participação. O mapeamento dessa atuação é de ampla divulgação, como se pode verificar da seguinte notícia: “BNDES vai investir R $\$ 1$ bi em empresas - Quantia está prevista até 2014 e aplicação será por meio de fundos que comprar participações em companhias. Foco será em empresas de médio porte; banco estatal vai criar mais dois fundos de 'private equity' neste ano. Empresas, principalmente de médio porte, que estão cada vez mais na mira dos investidores, vão receber R\$ 1 bilhão do BNDES até 2104. A instituição aplicará esse valor por meio de fundos que compram participações em empresas para desenvolvê-las e ganhar com sua valorização (os chamados fundos de 'private equity', 'venture capital' e capital semente). De acordo com Luciano Coutinho, presidente do BNDES, o banco vai criar pelo menos mais dois fundos de 'private equity' em 2012. E, por meio de todos os fundos desse tipo nos quais tenha participação até 2014, vai investir R\$ 1 bilhão. Hoje, o BNDES participa de 29 fundos de 'private equity', 'venture capital' e capital semente, com investimentos em 199 companhias. Em 2003, eram 15 fundos, com recursos em 24 empresas. 'Para cada real investido pelo BNDES [nesse projeto de $\mathrm{R} \$ 1$ bilhão até 2014], esperamos pelo menos mais $\mathrm{R} \$ 4$ vindos do mercado, de modo que possamos passar essa quantia para R 5 bilhões', ressaltou Coutinho. 'A estrutura empresarial brasileira tem muitos diamantes não polidos que podem ser muito bem aproveitados se forem levados a uma

11 GRAU, Eros. A ordem econômica na Constituição de 1988: interpretação e crítica. 13. ed. São Paulo: Malheiros, 2008. p. 90-100; GRAU, Eros. Elementos de direito econômico. São Paulo: Malheiros, 1981. p. 58-81; GRAU, Eros. Planejamento econômico e regra jurídica. São Paulo: RT, 1977. p. 23-27; GRAU, Eros. O direito posto e o direito pressuposto. 7 ed. São Paulo: Malheiros, 2008. p. 118-147; GRAU, Eros. Direito, conceitos e normas jurídicas. São Paulo: Malheiros, 1988. p. 109-114; GRAU, Eros; FORGIONI, Paula. O Estado, a empresa e o contrato. São Paulo: Malheiros, 2005. p. 213. 
gestão mais profissionalizada', acrescentou. Com a valorização do real, ficou mais custoso, em dólares, investir em companhias brasileiras - o que tem contribuído para que os grandes fundos olhem mais para empresas de porte intermediário, menos caras". ${ }^{12}$

30. A atuação do Estado sobre a economia dos fundos de investimento por direção e indução tem um longo histórico, que contextualiza e dá sentido, inclusive, à contemporânea atuação do Cade junto a tais entes econômicos. ${ }^{13}$ No caso da atuação sobre a economia dos fundos de investimento por indução, a regulação tributária é farta, tentando, nos últimos anos, conferir atratividade a tais formas econômicas, com razoável sucesso. ${ }^{14} \mathrm{~A}$ atuação sobre a economia dos fundos de investimento por direção vem sendo objeto de um longo aprendizado, que simultaneamente (i) organiza a atividade econômica privada e suas formas jurídicas, (ii) como o aparato institucional (competências, orçamento e definições políticas) de fiscalização e controle. ${ }^{15}$

12 Folha de S.Paulo, 17 abr. 2012. Mercado, B-5.

13 Essa necessidade de penetrar no âmbito da história das instituições para realizar a regulação mais adequada é compartilhada por YASBEK, Otávio. Regulação do mercado financeiro $e$ de capitais no Brasil. 2. ed. Rio de Janeiro: Elsevier, 2009. p. 259: "No Brasil, a despeito das peculiaridades da regulação financeira, do conceito por demais genérico de instituição financeira, da coexistência de diversos reguladores e de uma base legal bastante diversificada e que soa, a uma primeira vista, contraditória (peculiaridades, a bem da verdade, também presentes em outros países), as atividades de regulação parecem, também, vir se adequando a tais critérios e aos movimentos internacionais que os informam. Assim, ao lado de reguladores especializados em determinadas áreas (seguros, previdência privada e capitalização, a CVM vem, cada vez mais, se afirmando como um regulador geral de condutas nos mercados de instrumentos negociáveis (ou seja, de proteção ao consumidor), enquanto o BCB, por sua vez, vem se afirmando como um regulador prudencial e sistêmico (até por ser regulador bancário). Os demais reguladores restam incumbidos, também, da regulação de condutas, em suas áreas específicas. A uma primeira vista parece, assim, que o sistema de regulação brasileiro vem se organizando para lidar com aqueles riscos, individuais e sistêmicos, decorrentes das inovações financeiras e das novas modalidades organizacionais que se apresentam. A solução é mais complexa, naturalmente, do que a simples dicotomia entre mercado financeiro e mercado de capitais, existente na origem daquelas instituições. É justamente por essa mutação das atividades dos reguladores que se impõem novas considerações. Isso porque ela coloca em pauta a questão da relação entre as estruturas regulatórias e os processos históricos que a elas levaram. As estruturas regulatórias não são compostas apenas pelo 'estado da arte', mas elas trazem consigo, na verdade, diversos elementos próprios de soluções passadas. Instrumentos novos e antigos usualmente se combinam, no dia a dia da regulação, tendo em vista as finalidades buscadas e as peculiaridades dos mercados locais".

${ }^{14}$ Certamente faz parte desse acúmulo institucional a experiência com o "157", descrita em TRUBEK, David; VIEIRA, Jorge; SÁ, Paulo. Direito, planejamento e desenvolvimento do mercado de capitais brasileiro - 1965-1970. 2. ed. São Paulo: Saraiva, 2011.

15 Sobre o tema, com abordagens distintas, cf. Yasbeck, Regulação do mercado financeiro e de capitais no Brasil, op. cit., p. 263-286; FREITAS, Ricardo. Natureza Jurídica dos fundos de investimento. São Paulo: Quartier Latin, 2006. p. 79-90. 
31. De maneira tópica, podem ser mencionados alguns diplomas diretivos relevantes, iniciando-se em maio de 1945, quando foi promulgado o Decretolei n. 7.583, que permitiu a criação não só das sociedades de investimento, mas também das de crédito e financiamento, delegando poderes legislativos ao Ministério da Fazenda para a regulamentação da matéria; tais poderes vieram a ser transferidos para a Superintendência da Moeda e do Crédito (Sumoc).

32. Em agosto de 1946 o Decreto-lei n. 9.603 permitiu que pessoas naturais ou jurídicas cujas atividades o justificassem pudessem organizar seções de financiamento ou de crédito, mantendo-se o regime do Decreto-lei n. 7583.45.

33. A Constituição de 1946 atribui competência à União para fiscalizar as operações de estabelecimento de crédito, capitalização e de seguro, bem como legislar sobre normas de Direito Financeiro e sobre instituições de crédito.

34. A Portaria do Ministério da Fazenda n. 309, de 30 de novembro de 1959, alterava profusamente a atuação das sociedades de crédito, financiamento e investimento, com a justificativa de que cabia a elas papel complementar na dinamização do processo de desenvolvimento do país e pela necessidade de distinguir entre a atuação destas e a dos bancos comerciais.

35. Os fundos de investimento vieram a ser disciplinados, sumariamente, pela Lei n. 4.728, de 14 de julho de 1965, que atribui competência ao Conselho Monetário Nacional (CMN) para a regulamentação da matéria. Em 10 de dezembro de 1968, o Banco Central do Brasil, atendendo deliberação do Conselho Monetário Nacional, decide em seu inciso IV "vedar às sociedades de crédito, financiamento e às de tipo misto a constituição, administração ou gerência de Fundos Mútuos de Financiamento, ou Fundos de 'Acceptance', e, ainda, a partir dessa data, a colocação de novas cotas de Fundos que funcionem sob o regime de sociedade em conta de participação, condomínio ou quaisquer outras formas, assim entendido, para os efeitos deste item uma comunhão de recursos destinados à aplicação em operações de crédito, com base em papéis comerciais". ${ }^{16}$

16 Cf. Freitas, Natureza Jurídica dos fundos de investimento, op. cit., p. 81-82: “O inconformismo foi imediato. As associações de empresas de crédito, financiamento e investimento endereçaram solicitação ao Governo, ressaltando a importância dessa atividade e pedindo que sua legalidade fosse restabelecida. É muito importante atentar que o que se extinguiu naquele momento foi a figura do fundo enquanto aporte de recursos em uma sociedade de financiamento ou em conta de participação, ou, como referiu Rubens Requião, dos 'fundos de financiamento mantidos pelas sociedades de investimentos ou financeiras'. A preocupação do Banco Central era que instituições financeiras pudessem quebrar com a má condução dos investimentos de seus clientes. A solução, negociada com o Governo ao longo dos meses seguintes, foi estruturar uma nova figura jurídica que não fosse reconduzível à forma da sociedade em conta de participação. O centro das atenções passou a ser a figura do condomínio". 
36. Em abril de 1970 foi promulgada a Resolução Bacen n. 145, criando a figura do Fundo Mútuo de Investimento. ${ }^{17}$ Em 1974 , o Decreto-lei n. 1.376/74 cria o Finor (Fundo de Investimentos do Nordeste), Finam (Fundo de Investimentos da Amazônia) e o Fiset (Fundo de Investimentos Setoriais).

37. A edição do conjunto de leis que simultaneamente regula as sociedades anônimas cria a Comissão de Valores Mobiliários e organiza o sistema de previdência complementar privada, durante a década de 1970, entretanto, será provavelmente o agregado institucional mais frutífero para a economia dos fundos de investimento, pois, com a criação da Comissão de Valores Mobiliários (CVM) pela Lei 6.385, em 7 de dezembro de 1976, o legislador redefine a atribuição de competências tanto do CMN quanto do Banco Central do Brasil e CVM.

38. Esse agregado gestará uma cultura que culminará, nos anos 1990, com a criação dos chamados "fundos commodities" e a permissão dada pelo Comunicado-Conjunto do Banco Central do Brasil e da CVM n. 43, de 11 de março de 1992, para que os investidores estrangeiros do então existente anexo IV à Resolução n. 1289/87 pudessem adquirir cotas desses fundos.

39. Essa bipartição entre Bacen e CVM vigorou por bastante tempo, levando à criação de diversas espécies de fundos de investimento, disciplinadas em diplomas jurídicos próprios. "O CMN, no entanto, limitou-se, no passado, a atribuir à CVM poderes para 'baixar as normas e adotar as medidas que entender necessárias relativamente à constituição e funcionamento dos 'Fundos Mútuos de Ações', conforme redação do artigo 3o, da Resolução n. 1.787, de $1^{\text {o }}$ de janeiro de 1991, ressaltando, no par. $1^{\text {o }}$ do mesmo artigo que 'o Banco Central deve ser previamente ouvido quando se tratar da introdução de limites máximos de aplicação recursos dos Fundos referidos nesse artigo em títulos de crédito'. Com a alteração introduzida no diploma das

17 Ibid., p. 82-83: “Nasce aqui, assim, o primeiro regime jurídico de uma estrutura de fundo semelhante à que encontramos hoje. A Resolução n. 145/70 atendia aos anseios dos investidores e dos administradores, que poderiam seguir com seus objetivos de investimento e, por outro lado, apaziguava também os receios do Banco Central mencionados anteriormente. Reconheciase o fundo como uma estrutura condominial, que deveria ter seus atos constitutivos inscritos no registro competente e inscrição própria no cadastro dos contribuintes da Receita Federal, constituindo, no entendimento do legislador, propriedade dos cotistas e não do administrador. A importância da Resolução n. 145/70, como criadora da figura do fundo de investimentos em sua atual forma típica, fez-se sentir até na maneira como o Governo passou a estruturar programas e incentivos fiscais. (...) Após a concepção de fundo de investimento como figura típica introduzida pela Resolução n. 145/70, o Governo passou a estruturar seus programas de incentivo fiscal sempre desta forma: recursos do fundo segregados do patrimônio do administrador, emissão de cotas etc.". 
sociedades anônimas pela Lei n. 10.303, de 31 de outubro de 2001, o legislador classificou expressamente as cotas de fundo de investimento como valores imobiliários, tendo a CVM, finalmente, assumido a competência para regulamentar plenamente a matéria (artigos 2ㅇ, V e 8ㅇ, I). Com o objetivo de implementar efetivamente as mudanças estruturais necessárias à unificação normativa, foi celebrado, em 5 de julho de 2002, um convênio entre a CVM e o Banco Central, visando ao intercâmbio de informações e outras atividades correlatas. Como fruto do esforço conjunto desenvolvido a partir do convênio, a unificação finalmente materializa-se com a entrada em vigor da Instrução CVM n. 409, de 18 de agosto de 2004, pois todas espécies de fundo reguladas e supervisionadas pelo Banco Central viram-se obrigadas a se adequar aos termos da referida Instrução até 31 de janeiro de 2005 (por força do disposto no artigo $1^{\circ}$ da Instrução CVM n. 413, de 30 de dezembro de 2004), data a partir da qual tornaram-se inaplicáveis as normas emanadas pelo Banco Central do Brasil que disciplinavam seu regramento". ${ }^{18}$

40. Essa evolução organizou os inúmeros tipos de fundos de investimento, que se encontram sistematizados pela Comissão de Valores Mobiliários e pelo soft law articulado e expedido pelas associações setoriais e seus códigos orientadores.

\section{E. Atuação do Estado sobre a economia dos fundos de investimento: a im- portância da defesa da concorrência}

41. A atuação do Estado sobre o domínio econômico por direção deve ocorrer também para garantir a concorrência. Como pondera o atual diretor da Comissão de Valores Mobiliários Otávio Yasbek, em obra acadêmica mas de grande alcance prático: “(...) os mecanismos de defesa da concorrência são usualmente colocados em segundo plano quando da discussão da regulação financeira. (...) Não obstante, não é possível simplesmente ignorar o papel dessa modalidade tão peculiar de regulação ou a importância da concorrência como bem a ser tutelado, mesmo porque, ao criar barreiras à entrada para os agentes, assim como outras diversas limitações, a regulação financeira típica não deixa de permitir distorções e, eventualmente, de gerar outras ineficiências. Nesse sentido, Goodhart et al. (1998, p. 167 e ss.) apontam a importância da integração entre o regime de proteção à concorrência e a regulação setorial, de modo a permitir, para aquele primeiro, a aquisição

18 Ibid., p. 94-95. 
de um grau de especialização que a sensibilize para as peculiaridades desta última. Ainda que nem sempre sejam desenvolvidos tais mecanismos de integração, a tendência mundial parece ser a de reforço da competência da autoridade antitruste, reforçando a complementaridade entre as duas formas de intervenção estatal" ${ }^{19}$ Da mesma maneira expressou-se a atual Presidente da Comissão de Valores Mobiliários, em reportagem do Valor Econômico de dezembro de 2011, com título “CVM quer mais competição na indústria de fundos". ${ }^{20}$

\section{F. Desafios da regulação dos fundos de investimento}

42. A dinâmica da realidade econômica, somada à história institucional acima sobrevoada, leva a uma série de desafios para os agentes de regulação, em seu conjunto. Os quadros abaixo foram montados para pensar o quadro geral de desafios regulatórios no sistema financeiro, mas sem dúvida é pertinente à específica questão dos fundos de investimento. Ainda que de maneira preliminar, pode-se apontar as principais ou mais prováveis intersecções com a política de defesa da concorrência.

19 Yasbeck, Regulação do mercado financeiro e de capitais no Brasil, op. cit., p. 207.

20 Valor Econômico, 9, 10 e 11 de dezembro de 2011, D-3: “CVM quer mais competição na indústria de fundos - Outro ponto que podemos evoluir bastante é como fazer com que o investidor potencial seja mais sensível a preço, pela vontade de ter um rendimento líquido melhor, buscando produtos concorrentes e trazer essa dinâmica saudável para dentro do mercado. Uma parte é questão de transparência, que vamos editar logo. Outra parte pode ser permitindo que a indústria realize economias de escala. Tudo indica que é o principal fator que influencia no custo das taxas de administração de fundos de investimento é a escala. Temos uma regra que segmenta necessariamente por público, na medida em que só permite que os fundos tenham uma classe de cotas. Será que essa é a melhor forma de estruturar esse mercado? Queremos discutir isso. (...) Outro desafio é como melhorar os canais de distribuição de um maior número de fundos. Como fazer para que outras formas de distribuir possam florescer aqui e tenham viabilidade econômica. (...) A regulamentação atual [Instrução 461] já permite o estabelecimento de várias bolsas. Mas nós queremos fazer uma avaliação mais profunda do mercado, sobre essa regulamentação e o mercado que temos hoje, em que o prestador também é dono de infraestruturas de pós-negociação, como instituição depositária e 'clearing'. Queremos entender que impacto isso tem também como forma de barreira de entrada. Mas sempre dentro de um contexto em que o objetivo final é o funcionamento eficiente de mercado e não a concorrência. Esperamos que esse estudo nos dê subsídios para avaliar se há algo que precisa mudar na regulamentação". 
Medidas regulatórias e objetivos da regulação (Yasbek, p. 255)

\begin{tabular}{|c|c|c|c|c|}
\hline Medidas Regulatórias & $\begin{array}{l}\text { Risco } \\
\text { Sistêmico }\end{array}$ & $\begin{array}{l}\text { Proteção do } \\
\text { Consumidor }\end{array}$ & Eficiência & $\begin{array}{l}\text { Objetivos } \\
\text { Sociais }\end{array}$ \\
\hline Política de competição/antitruste & & $x$ & $x$ & $x$ \\
\hline Padrões de disclosure & $x$ & $x$ & $x$ & \\
\hline Regras de conduta negocial & & $x$ & $x$ & $x$ \\
\hline Regras sobre conflitos de interesses & & $x$ & $\mathrm{x}$ & \\
\hline Adequação patrimonial/de capital & $\mathrm{x}$ & $x$ & & \\
\hline Mecanismos de controle de acesso & $x$ & $x$ & $\mathrm{X}$ & \\
\hline Regras sobre manutenção de liquidez & $\mathrm{X}$ & $\mathrm{x}$ & & \\
\hline Comunicações/relatórios obrigatórios & & & & $x$ \\
\hline Restrições sobre prestação de serviços & $x$ & & & $\mathrm{x}$ \\
\hline Restrições sobre detenção de ativos & $x$ & & & $x$ \\
\hline Mecanismos de seguro de depósito & $x$ & $x$ & & \\
\hline Obrigação de manutenção de reservas & $\mathrm{x}$ & $x$ & & \\
\hline $\begin{array}{l}\text { Obrigação de adequação das } \\
\text { operações ao perfil dos clientes }\end{array}$ & & $x$ & & \\
\hline $\begin{array}{l}\text { Limitação de taxa de juros sobre } \\
\text { depósitos }\end{array}$ & $x$ & & & $x$ \\
\hline $\begin{array}{l}\text { Limitação de taxa de juros sobre } \\
\text { empréstimos }\end{array}$ & & $\mathrm{x}$ & & \\
\hline $\begin{array}{l}\text { Obrigação de realizar/direcionar } \\
\text { investimentos }\end{array}$ & & & & $\mathrm{x}$ \\
\hline Restrições geográficas & & & & $x$ \\
\hline
\end{tabular}


Medidas regulatórias e objetivos — falhas de mercado (Yasbek, p. 257)

\begin{tabular}{|c|c|c|c|c|}
\hline Medidas Regulatórias & $\begin{array}{l}\text { Comportamento } \\
\text { Anticompetitivo }\end{array}$ & $\begin{array}{l}\text { Más Práticas } \\
\text { Negociais }\end{array}$ & $\begin{array}{l}\text { Informações } \\
\text { Assimétricas }\end{array}$ & $\begin{array}{l}\text { Instabilidade } \\
\text { Sistêmica }\end{array}$ \\
\hline $\begin{array}{l}\text { Competição } \\
\text { Politica de estrutura de mercado } \\
\text { Regras anticolusão } \\
\text { Regras garantidoras da concorrência }\end{array}$ & $\begin{array}{l}X \\
X \\
X\end{array}$ & & & \\
\hline $\begin{array}{l}\text { Conduta de mercado } \\
\text { Disclousure } \\
\text { Conduta negocial } \\
\text { Obrigações fiduciárias/de governança }\end{array}$ & & $\begin{array}{l}X \\
X \\
X\end{array}$ & & \\
\hline $\begin{array}{l}\text { Regulação prudencial } \\
\text { Regras para acesso } \\
\text { Regras para patrimônio/capital } \\
\text { Demonstrações financeiras } \\
\text { Relações entre instituições } \\
\text { Manutenção de liquidez } \\
\text { Transparência } \\
\text { Mecanismos de seguro/salvaguarda }\end{array}$ & & $\begin{array}{l}x \\
X\end{array}$ & $\begin{array}{l}X \\
X \\
X \\
X \\
X \\
X \\
X\end{array}$ & $\begin{array}{l}X \\
X \\
X \\
X \\
X \\
X \\
X\end{array}$ \\
\hline $\begin{array}{l}\text { Redundâncias } \\
\text { Obrigação de adequação das } \\
\text { operações ao perfil dos clientes } \\
\text { Limitação de taxa de juros } \\
\text { - sobre depósitos } \\
\text { - sobre empréstimos } \\
\text { Realização/alocação de } \\
\text { investimentos } \\
\text { Restrições geográficas }\end{array}$ & & & & \\
\hline
\end{tabular}

43. Como se vê, existe um largo campo para a articulação orgânica da regulação dos mercados financeiros, como um todo, e a regulação sobre os fundos de investimento, em específico, pensadas a partir da égide da defesa da concorrência.

44. Esse é um desafio institucional de largo fôlego, que, certamente, deve estar no centro das preocupações do Conselho Administrativo de Defesa Econômica nessa sua nova fase de atuação, realizando um amplo trabalho de capacitação interna e de articulação com as demais agências competentes, a fim de que a sociedade tenha barreiras protetivas contra as consequências indesejadas de práticas econômicas danosas (ainda que amparadas em corpo aparentemente sólido de ideias e organização jurídica formalmente impecável). 


\section{G. Atuação do Estado sobre a economia dos fundos de investimento: a atuação do Cade até agora}

45. Esse desafio futuro não precisa ser desconectado do acúmulo e aprendizado institucional realizado pelo Cade até o momento. Eventualmente o Cade pode não ter desenvolvido os mecanismos de análise mais sofisticados para monitorar o grau de concentração que alguns fundos possam ter impresso em determinados mercados relevantes, ou mesmo não ter sido capaz de mapear a dinâmica da troca de informações entre investidores, gestores, administradores da maneira mais eficaz e exata, mas sem dúvida a atuação até o momento existente trouxe um aprendizado que servirá como acúmulo para a nova fase e os novos desafios.

46. Levantamento preliminar realizado por meu gabinete, coletando como amostra estatística os últimos 50 casos envolvendo Fundos de Investimento julgados pelo Conselho, traz os seguintes resultados: (i) Conclusão do caso: 96\% de aprovações e 4\% de arquivamentos; (ii) Justificativas quanto ao mérito: $64 \%$ - "substituição de agente econômico", 22\% - "baixa sobreposição horizontal", 14\% - outros; (iii) Justificativas sobre requisitos para o conhecimento: $68 \%$ - "faturamento" e 32\% - "influência + faturamento".

47. Esse levantamento, como afirmado, é preliminar, devendo ser objeto ainda de checagem posterior, que amplie o espaço amostral, bem como faça uma revisão nos próprios dados colacionados até o momento. De qualquer modo, ele aponta para algumas linhas-mestras sobre o campo investigado: (i) o tipo de fundo de investimento que vem apresentando operações à autoridade concorrencial e (ii) quais as principais questões debatidas e suas soluções.

48. A maioria dos casos trazidos à apreciação do Conselho refere-se certamente aos Fundos de Investimento em Participações (FIPs) e aos Fundos Mútuos de Investimento em Empresas Emergentes (FMIEEs). Os fundos de investimento em participações são via de regra assemelhados aos fundos de private equity e os fundos mútuos de investimento em empresas emergentes, via de regra, tomados como os fundos de venture capital, sendo submetidos a regulação da CVM, entre outras, através das instruções 209/94 e 391/2003, que determinam que os fundos a ela submetidos tratam-se de fundo de investimento constituído na forma de condomínio fechado ${ }^{21}$ que têm, como

21 “Art. 2o - O Fundo de Investimento em Participações (fundo), constituído sob a forma de condomínio fechado, é uma comunhão de recursos destinados à aquisição de ações, debêntures, bônus de subscrição, ou outros títulos e valores mobiliários conversíveis ou permutáveis em ações de emissão de companhias, abertas ou fechadas, participando do processo decisório da companhia investida, com efetiva influência na definição de sua política estratégica e na sua gestão, notadamente através da indicação de membros do Conselho de Administração." 
nota característica, a participação no processo decisório da companhia investida, com efetiva influência na definição de sua política estratégica e de sua gestão (art. 2º ). Essa "participação no processo decisório" pode se dar por meio da detenção de ações do bloco de controle, por meio de acordo de acionista, ou por qualquer outro meio que lhe assegure efetivamente essa participação. $^{22}$

49. Nos termos do "Segundo Censo Brasileiro da Indústria de Private Equity e Venture Capital”, "as estatísticas que refletem a consolidação desse segmento diferenciado da indústria brasileira de intermediação financeira, especializado na criação de valor e gestão de empreendimentos, mostravamse nas telas do radar de investidores globais, interessados nas dinâmicas econômicas emergentes. No início de 2005, existiam 71 organizações gestoras com não mais do que US\$ 6 bilhões em veículos de investimento (fundos) de PE/VC, o equivalente a 0,7\% do PIB. Ao fim de 2009, 144 gestores administravam comprometimentos de capital de US\$ 36,1 bilhões alocados ao Brasil, 2,3\% do PIB. Essas organizações gestoras empregavam em torno de 1.593 profissionais, dos quais 2/3 detinham formação superior. Essas organizações possuíam participação acionária e realizavam governança ativa em 502 empresas, a maioria fechadas ou levadas à abertura de capital em bolsa por aqueles gestores de $\mathrm{PE} / \mathrm{VC}^{\prime \prime}{ }^{23}$

50. Ainda segundo o Censo, uma das razões do aumento da importância dessa indústria deve-se a que "o Brasil vem se destacando recorrentemente pelo grande número de empreendedores (...) Porém, a proporção de empreendedores por oportunidade - pessoas que criam um negócio para atender a uma necessidade do mercado - ainda é baixa em comparação com países com forte cultura empreendedora. Essa baixa proporção se deve, em parte, à escassez de financiamento de longo prazo no Brasil”. Essa indústria serviria como uma alternativa ao tradicional sistema de financiamento, principalmente bancário, uma vez que "no Brasil é pouco usual que os bancos privados concedam financiamento de longo prazo para as empresas e apenas os bancos e órgãos de fomento fazem esse tipo de operação. As empresas

22 Na dicção do art. 2º da Instrução CVM 409/2004, os fundos são organizados juridicamente na forma de condomínio, por meio da comunhão de recursos destinados à aplicação em ativos no mercado financeiro e de capitais. As implicações concorrenciais, entretanto, como se verá adiante, são muito mais complexas do que a mera menção a tais arranjos jurídicos pode deixar transparecer.

23 ABDI; GVCEPE. A indústria de private equity e venture capital. 2o Censo Brasileiro. Brasília: ABDI, 2009. p. 30. 
brasileiras, em especial as MPMEs, sofrem com essa segmentação de crédito $(\ldots)^{\prime \prime} \cdot{ }^{24}$ Essa alternativa parece ainda ser reforçada pelos dados da Empea Emerging Markets Private Equity Association, segundo os quais "os fundos dedicados ao Brasil bateram recorde de captação em 2011, com US\$ 7,08 bilhões. A China, por sua vez, atraiu US\$ 16 bilhões em recursos de fundos de private equity. Juntos, os dois países foram responsáveis por mais de $60 \%$ de todo o capital levantado para países emergentes, que ficou em US\$ 38,55 bilhões no ano passado. (...) Os fundos de private equity dedicados ao Brasil tiveram no ano passado a maior captação da série histórica acompanhada pela Empea (iniciada em 2002). Em 2011, foram levantados US\$ 7,08 bilhões para esses fundos, quase sete vezes mais do que o valor verificado em 2010 (US\$ 1,08 bilhão). (...) O relatório da Empea aponta ainda que uma característica verificada no Brasil ilustra muito bem uma diferença entre os mercados emergentes de hoje e o cenário de uma década atrás: todos os fundos levantados no País no ano passado são integralmente de companhias locais. Por outro lado, quase todo (95\%) capital angariado para o Brasil em 2011 veio somente de cinco fundos, sendo que cada um deles captou US\$ 1 bilhão ou mais, chegando juntos ao montante de US\$ 6,7 bilhões" ${ }^{25}$

51. Assim, considero importante visitar os principais termos dessa atuação do Cade, que parece ter-se centrado sobre "conhecimento de operações que poderiam ser vistas como simples operações financeiras", e não como "reais concentrações econômicas" nos termos do art. 54 da Lei 8.884/94.

52. Em 2002, no AC 08012.007112/2001-53, o Cade já se deparava com a questão de operações envolvendo fundos. Nas palavras do conselheiro relator Thompson Andrade, tratava "de mera operação financeira a título de garantia fiduciária, não havendo que se falar em limitação ou prejuízo à concorrência, dominação de mercado relevante de bens ou serviços ou mesmo concentração econômica, ou seja, a operação notificada não se enquadra em nenhum dos dispositivos elencados pela Lei". Em tal caso, arquivado sem julgamento de mérito por unanimidade, o Conselho entendeu que os critérios do art. 54, § 30 pressuporiam a existência de concentração econômica, o que não ocorreria no caso concreto.

53. Ainda em 2002, no AC 08012.006619/2001-90, o Conselho se deparou com a questão de investimentos de fundos de private equity. $\mathrm{O}$ conselheiro

24 Ibid., p. 336.

25 BRASIL e China puxam captação para fundos dedicados aos emergentes. Participações/Publicação sobre Gestores, Investidores e Investimentos em Private Equity, ano 3, n. 34, p. 16, abr. 2012. 
relator Thompson Andrade, seguindo o entendimento exarado no caso anterior e votando pela extinção do processo sem julgamento de mérito, entendeu que a operação representaria "uma mera operação financeira sob a forma de private equity [...] Não se observa[ndo], portanto, qualquer concentração horizontal ou integração vertical, não havendo que se falar em limitação ou prejuízo à concorrência, ou ainda dominação de mercado relevante". Entretanto, tal posicionamento foi vencido pela maioria do Conselho, que seguiu a orientação do voto do i. conselheiro Ronaldo Macedo. Segundo o referido conselheiro, a principal preocupação concorrencial seria quanto a natureza da influência que um fundo pode exercer sobre as estratégias comerciais da empresa-alvo. Diante de um objetivo de maximização de lucros, o fundo poderia influenciar as estratégias comerciais de uma companhia, de modo a prejudicar os consumidores e a concorrência. Indicou ainda a possibilidade da criação de estruturas facilitadoras de colusão decorrentes da atuação de fundos. Para o conselheiro, a tese de não conhecimento só poderia ser aplicada em casos de "manifesta incompatibilidade, in abstrato, da pretensão do autor." Ademais, aduziu quanto aos riscos de não se conhecer de uma operação, vez que poderia abrir significativo precedente para que empresas realizem determinadas operações e se sintam no livre arbítrio de notificar ou não suas operações. Essa é a opinião com que compartilho.

54. Após esse importante precedente, houve uma série de decisões, dentre as quais certamente incluem-se as da lavra do i. conselheiro Olavo Chinaglia, que merecem destaque especial pelo labor dispendido.

55. Diante da "grande quantidade de casos notificados que não oferecem quaisquer riscos ao ambiente concorrencial brasileiro" ${ }^{26}$ buscou-se a formulação de "critérios objetivos e abstratos" que permitissem a distinção $a b$ initio de "operações equiparáveis, para todos os fins e efeitos, a aplicações financeiras - como a aquisição de títulos de dívida pública ou privada, por exemplo - de operações que impliquem algum risco à dinâmica do processo de competição." ${ }^{27}$

56. Essa distinção teria por objetivo poupar os recursos privados ${ }^{28} \mathrm{e}$, sobretudo, garantir a maior eficiência e otimização dos recursos da Administração Pública, uma vez que "a apreciação dessas operações onera o Sistema Brasileiro de Defesa da Concorrência (SBDC), na medida em que consome

\footnotetext{
AC $08012.011111 / 2010-02$

AC $08012.009529 / 2010-41$

AC 08012.009529/2010-41
} 
os escassos recursos humanos e materiais da autarquia na apreciação de operações incapazes de limitar ou de qualquer forma prejudicar a livre concorrência". ${ }^{29,}{ }^{30}$ Com base em tais premissas e objetivos, o i. conselheiro veio Chinaglia veio lentamente trabalhando e burilando os caminhos de uma metodologia segundo a qual o conhecimento de tais operações estaria sujeito a condições predeterminadas. ${ }^{31}$

57. Mesmo não concordando com tal abordagem, esse esforço do i. Conselheiro Chinaglia, por si só, élouvável, entre outras razões, por demonstrar denodo intelectual e preocupações com a coerência sistêmica da atuação do Conselho. Por isso, deve ser emulado e analisado, o que acredito poder ser feito por meio da escolha de algumas decisões representativas. Faço essa releitura, simultaneamente, como uma homenagem e como um aprendizado, com o intuito de contribuir para o avanço de nosso conhecimento sobre nós mesmos, para o alcance do fim precípuo do órgão a que todos servimos com dedicação: uma economia que sirva corretamente à sociedade brasileira.

58. Nas decisões escolhidas, como não poderia deixar de ser, ocorre uma incremental aquisição de hipóteses e testes, levando a que as "condições predeterminadas" fossem sendo modificadas conforme, no entender do i. conselheiro, se mostrassem justificadas ou não. Parece-me, também, que esse exercício presente nas decisões sempre guardou humildade suficiente para ver-se, a si mesmo, como um teste e um aprendizado. Assim, julgo relevante a menção explícita aos seguintes votos do i. conselheiro Chinaglia, como um marco importante das discussões ora mapeadas: (a) 08012.004911/2010-69, (b) 08012.005573/2010-82; (c) 08012.005880/2010-63; (d) 08012.006989/2010-18; (e) $08012.009529 / 2010-41$; (f) 08012.0011111/2010-02; (g) 08012.008322/2011-31; (h) $08012.008727 / 2011-79$; e (i) 08012.010771/2011-49

\section{a) 08012.004911/2010-69}

59. Nessa operação, julgada em 23 de junho de 2010, foi apresentada a primeira metodologia para identificação de operações envolvendo fundos de investimentos "concorrencialmente relevantes". Conforme o teste proposto, haver-se-ia de perquirir a forma como se dá o processo de decisão (etapa 01) “(i) no âmbito do fundo, ou seja, quem define as estratégias de investimentos dos

\footnotetext{
29 AC 08012.004911/2010-69

30 Tal preocupação também se apresenta noAC 08012.009529/2010-41: “[com oque seria] otimizado o uso de recursos públicos escassos, que poderiam ser direcionados ao aprofundamento da análise de casos verdadeiramente relevantes sob a perspectiva concorrencial".

31 AC 08012.005573/2010-82
} 
recursos, e (ii) nas empresas-alvo do investimento, após o investimento. Caso fique demonstrado que os cotistas do fundo não interferem na administração e na gestão do fundo e, concomitantemente, que o fundo não interfere na administração da sociedade-alvo dos investimentos, temos um caso de não conhecimento, independentemente dos faturamentos e participações de mercado dos cotistas do fundo e das sociedades-alvo do investimento".

60. Caso se identificasse qualquer influência, seja dos cotistas sobre o fundo, seja do fundo sobre as sociedades-alvo, não se procederia a um conhecimento imediato da operação. Haveria, ainda, de se verificar o atendimento dos critérios legais estabelecidos na Lei 8.884/94, art. 54, § 3 (etapa 02). Assim, dever-se-ia verificar se: (i) as sociedades-alvo dos investimentos preenchem os requisitos; (ii) se os cotistas que exercem influência relevante na administração do fundo preenchem, isoladamente ou em conjunto, os requisitos legais; ou (iii) se o fundo detém participações em mais de uma empresa de um mesmo setor de atividade, situação na qual seria necessário verificar se elas, conjuntamente, atendem aos requisitos. Caso se verifique o atendimento dos requisitos legais em qualquer uma dessas situações, ter-se-ia um caso de conhecimento.

61. Na análise de mérito, o conselheiro relator analisou as relações de integração vertical e concentração horizontal entre a sociedade-alvo da operação e (i) os cotistas do fundo (destaca-se que no caso o relator entendeu configurada a influência dos cotistas sobre o fundo) e (ii) as sociedades que compõem o portfolio de investimentos do fundo.

\section{b) $\mathbf{0 8 0 1 2 . 0 0 5 5 7 3 / 2 0 1 0 - 8 2}$}

62. Essa operação foi julgada em 21 de julho de 2010. Nela, manteve-se integralmente a "etapa 01 ", pelo que, para o não conhecimento, haveria de ocorrer, concomitantemente, (i) a não influência dos cotistas do fundo sobre o fundo e (ii) a não influência do fundo sobre a sociedade-alvo.

63. Quanto à "etapa 02", houve uma pequena modificação, uma vez que se retirou a necessidade de verificar "se o fundo detém participações em mais de uma empresa de um mesmo setor de atividade" (situação 'iii'), para verificar o atendimento dos requisitos estabelecidos na Lei 8.884/94, art. 54, § 3o.

64. No mérito, as relações concorrenciais analisadas foram as existentes entre a empresa-alvo e (i) os cotistas do fundo (no caso, deve-se destacar que foi identificada a existência de influência dos cotistas sobre o fundo), (ii) demais empresas do portfolio de investimentos do fundo, e (iii) empresas do portfolio de outros fundos geridos pela gestora em questão. 
65. Este último ponto representa uma inovação em relação ao caso anterior. Entretanto, conforme pontuado pelo i. relator, "após refletir mais profundamente sobre esse ponto, considero que a possibilidade de um gestor de fundos de investimento induzir o comportamento colusório nas empresas investidas é remota, já que a perda em termos reputacionais para o gestor seria imensa, sobretudo em razão da natureza dos serviços por ele prestados. É preciso considerar ainda que a implementação de qualquer comportamento anticompetitivo dependeria da concordância da empresa-alvo dos investimentos, que em regra não é controlada pelo fundo de investimento representado pelo gestor. Apesar de tal hipótese não poder ser descartada, considerando-se que nunca houve denúncia ao SBDC de práticas dessa natureza, parece-me suficiente que, em prol da eficiência administrativa, esses casos sejam investigados no âmbito de controle de condutas, quando houver indícios de práticas anticompetitivas". Assim, no mérito voltou-se a analisar aquelas relações já indicadas no caso anterior.

c) $08012.005880 / 2010-63$

66. Trata-se de caso também julgado em 21 de julho de 2010. Ainda que não tenha realizado modificações teóricas acerca do teste proposto, analisando o caso concreto, diante da verificação de que o gestor do fundo pertencia ao mesmo grupo de seus cotistas (pelo o que se presumiria alguma forma de influência destes sobre o gestor), o Relator exarou o seguinte: "Se o caso em apreço envolvesse um fundo gerido por uma entidade independente dos cotistas, entendo que seria caso de não conhecimento porque os cotistas não teriam, por meio do fundo, possibilidade de influir nas decisões mercadologicamente relevantes da empresa. Se este fosse o caso, não estaríamos diante de uma concentração econômica".

67. Já se vislumbra de tal trecho uma alteração na "etapa 01" do teste originalmente proposto, pela qual não seria necessário o atendimento concomitante daqueles requisitos indicados originalmente. Tal modificação foi posteriormente incorporada formalmente à metodologia, conforme se mostrará mais a frente.

68. Neste caso, não houve alterações quanto à análise de mérito de casos envolvendo fundos de investimento.

d) $\mathbf{0 8 0 1 2 . 0 0 6 9 8 9 / 2 0 1 0 - 1 8}$

69. Neste caso, julgado em 4 de agosto de 2010, seguiu-se a metodologia empreendida na análise do AC 08012.005573/2010-82, tanto na questão atinente ao conhecimento quanto à questão da análise do mérito. 


\section{e) $\mathbf{0 8 0 1 2 . 0 0 9 5 2 9 / 2 0 1 0 - 4 1}$}

70. Trata-se de caso julgado em 9 de novembro de 2010. Neste caso foi realizado uma relevante modificação na "etapa 01" do teste proposto. Agora, uma operação só deveria ser conhecida se concomitantemente se constatasse (i) a influência dos cotistas sobre os gestores do fundo e (ii) que estes pudessem influenciar a administração da empresa-alvo. Assim, a contrario sensu, para uma operação não ser conhecida bastaria que não houvesse um desses quesitos (lembrando que, a meu ver, pela tese anterior, seria necessária a verificação concomitantemente desses elementos). No resumo do relator: “(...) caso fique demonstrado que os cotistas do fundo não interferem na administração e na gestão do fundo ou que o fundo não interfere na administração das sociedades-alvo dos investimentos, tem-se que a operação não precisa ser notificada, independente do faturamento e participações de mercado dos agentes envolvidos".

71. Nesta oportunidade, ainda, foram feitas algumas considerações acerca do papel dos administradores dos fundos, nos seguintes termos: “(...) é pouco crível que algum investidor concorde em deixar os seus recursos sob a responsabilidade de alguém que esteja sendo investigado, por exemplo, por incentivar a adoção de condutas concertadas entre as empresas nas quais os fundos por ele administrados aportaram tais recursos. E diante disso, o controle ex post, por meio da repressão às condutas anticompetitivas, pareceme suficiente para endereçar satisfatoriamente a atuação dos gestores dos fundos de investimento". Como consequência, seria desnecessário verificar se o administrador do fundo envolvido na operação participaria, também como administrador, de outros fundos de investimento. Trata-se, pois, de entendimento que corrobora o que foi anteriormente mencionado no AC 08012.005573/2010-82.

72. Na "etapa 02" houve também algumas alterações. Estabeleceu-se que deveriam ser considerados de forma individualizada os faturamentos dos cotistas que exerçam influência relevante sobre a administração do fundo (antes, me parece, havia se apontado para que se pudesse considerar os cotistas de forma conjunta, para fins do preenchimento dos requisitos legais). Segundo o i. relator, não seria razoável presumir a existência de um grupo econômico entre os cotistas apenas em decorrência de que fizeram investimentos em um mesmo fundo.

73. No mérito, manteve-se a forma de análise anteriormente definida.

\section{f) $08012.0011111 / 2010-02$}

74. Trata-se de caso julgado em 15 de dezembro de 2010, e que, ao menos no que me foi possível identificar, foi o primeiro caso em que não se conheceu 
de uma operação em decorrência da aplicação da metodologia aqui analisada. Para a análise desse caso, empreendeu-se o teste conforme definido no caso anteriormente citado.

75. No caso concreto, segundo o relator, observou-se “(...) a existência de um fundo de investimento conduzido por administradoras e gestores independentes dos cotistas. Nessa hipótese, a atuação dos gestores do fundo teria como finalidade única o rendimento financeiro auferido pela investida e o ganho de capital na alienação da participação, não se equiparando a um ato de concentração econômica".

\section{g) 08012.008322/2011-31}

76. Trata-se de operação julgada em 26 de outubro de 2011, e que não propôs nenhuma nova alteração na tese desenvolvida. Apenas destaca-se que, quanto à "etapa 02", o i. relator voltou a indicar a possibilidade de se considerar os cotistas de forma conjunta para fins de preenchimento dos critérios legais, ou seja, não se utilizou da proposta feita no AC 08012.009529/2010-41.

77. No mérito também não houve alterações.

h) 08012.008727/2011-79

78. Caso julgado em 23 de novembro de 2011 em que a análise empreendida seguiu a metodologia do caso anterior, inclusive com a ressalva feita na "etapa 02".

i) $08012.010771 / 2011-49$

79. Trata-se da mais recente operação em que se discutiu a tese (julgada em 14 de março de 2012), não conhecida em decorrência da aplicação da metodologia. Nessa decisão, verificou-se divergência no Conselho, com três conselheiros votando pelo conhecimento da operação.

80. Conforme restou consignado no voto do relator, “(...) a ausência de influência dos investidores na administração e gestão do fundo ensejaria o não conhecimento do ato, visto que suficiente para afastar preocupações concorrenciais quanto à possibilidade de o investidor fazer uso de usa participação societária para intervir no processo de decisão das sociedades-alvo, utilizando-se do fundo como meio de estabelecer alguma forma de coordenação entre as empresas investidas".

81. Esse conjunto de decisões é, além de fruto de grande esforço para realizar abordagem sistemática de uma questão, um manancial rico de hipóteses e outras perguntas (o que, aliás, é sempre o melhor resultado de um esforço intelectual: levar a mais perguntas). Aqui, rendo, mais uma vez, homenagens a tal esforço, relembrando os ensinamentos de nosso professor comum, Eros Roberto Grau: “A INTERPRETAÇÃO DO DIREITO É UMA 
PRUDÊNCIA. A interpretação do direito é uma prudência - o saber prático (...) a que se refere Aristóteles. Cogitam os que não são intérpretes autênticos, quando do direito tratam, da juris prudentia, e não de uma juris scientia; o intérprete autêntico, ao produzir normas, pratica a juris prudentia, e não juris scientia. O intérprete atua segundo a lógica da preferência, e não conforme a lógica da consequência [Comparato]: a lógica jurídica é a da escolha entre várias possibilidades corretas. Interpretar um texto normativo significa escolher uma entre várias interpretações possíveis, de modo que a escolha seja apresentada como adequada [Larenz]. A norma não é objeto de demonstração, mas de justificação. Por isso, a alternativa verdadeiro/falso é estranha ao direito; no direito há apenas o aceitável (justificável). O sentido do justo comporta sempre mais de uma solução [Heller]. Daí por que afirmo que a problematização dos textos normativos não se dá no campo da ciência: ela opera no âmbito da prudência, expondo o intérprete autêntico ao desafio desta, e não daquela. São distintos um e outro: na ciência, o desfio de, no seu campo, existirem questões para as quais ela (a ciência) ainda não é capaz de conferir respostas; na prudência, não o desafio de respostas, mas da existência de múltiplas soluções corretas para uma mesma questão [Adomeit]. (...) Dáse na interpretação de textos normativos algo análogo ao que se passa na interpretação musical. (...) Nem mesmo o juiz Hércules [Dworkin] está em condições de encontrar para cada caso uma resposta verdadeira, pois aquela que seria a única resposta correta simplesmente não existe. $O$ fato é que, sendo a interpretação convencional, não possui realidade objetiva com a qual possa ser confrontado o seu resultado (o interpretante), inexistindo, portanto, uma interpretação objetivamente verdadeira [Zagrebelsky]". ${ }^{32}$

82. A partir desse substrato, no qual lida-se com fatos e textos normativos, a fim de resolver questões práticas - fazer prudência - , certamente é um resultado vitorioso dessa empreitada deixar reflexões acumuladas e questões para o futuro em aberto.

\section{H. Práticas concorrencialmente sensíveis na indústria do private equity e venture capital}

83. Nessa senda, proponho-me também a fazer algumas perguntas sobre o tema em questão, a fim de tentar auxiliar nesse esforço coletivo. Quais são os aspectos concorrencialmente sensíveis trazidos pela indústria do Private

32 GRAU, Eros. Ensaio e discurso sobre a interpretação/aplicação do direito. 5. ed. São Paulo: Malheiros, 2011. p. 39-40. 
Equity? Que perguntas deveríamos estar fazendo a essa indústria, para garantir o bem tutelado pelo Cade - um saudável ambiente concorrencial?

84. Acho que um bloco razoável de perguntas pode ser sistematizado nos seguintes assuntos: (i) Consolidação de setores como fator gerador de valor; (ii) Controle das atividades das investidas como fator gerador de valor; (iii) Proximidade intensa entre os diversos atores como fator gerador de valor; (iv) Não apresentação de operações ao SBDC.

85. Como modo de iniciar a resposta a essas perguntas, acredito que o recurso a uma obra insuspeita, como o Manual de private equity e venture capital: passos para atração de investidores e alocação recursos (capital de risco, plano de negócios, avaliação de empresas, fundos de investimento, fusões e aquisições, casos práticos nacionais) ${ }^{33}$ possa ser de grande valia. Como todo manual, tem a pretensão de ser um guia prático, de resolver problemas; no caso específico, de propiciar ao investidor e gestor de tais fundos o melhor conhecimento sobre a área. ${ }^{34}$

\section{i. Consolidação de setores como fator gerador de valor: prática concor- rencialmente sensível}

86. Dentre as diversas questões concorrencialmente sensíveis trazidas pela prática dos fundos de private equity e afins, certamente sua estratégia de consolidação de setores inteiros sob as mãos de um único comando é uma das mais importantes.

87. Essa forma de agir é assim explicada aos atores da atividade: "Conforme citado anteriormente, os fundos apreciam fortemente a palavra consolidação, tendo preferência por comprar empresas que possam adquirir outras do mesmo segmento" (p. 140-141). "Os Fundos PE podem estar buscando aproveitar possibilidades de consolidação do segmento a partir da aquisição de algum participante do mesmo. Os gestores respeitam critérios de segmentação para obterem ganhos de escala nos investimentos, maior especialização e sinergias entre os mesmos. A segmentação é uma prática usual da indústria de fundos (...). A especialização por indústria permite ao gestor

33 ROSSI, Luiz. Manual de private equity e venture capital: passos para atração investidores e alocação recursos (capital de risco, plano de negócios, avaliação de empresas, fundos de investimento, fusões e aquisições, casos práticos nacionais). São Paulo: Atlas, 2010.

34 O recurso à leitura de manuais, aliás, possui uma história profícua na economia política: os manuais para "conquistar e manter o poder", como O príncipe, de Maquiavel, ou os manuais de "defesa da economia nacional", como o Report on manufactures ou o Report on public credit, de Alexander Hamilton, revelam mais ao pensamento investigador sobre a realidade do que a maioria dos textos que pretendeu compreender os mesmos problemas. 
obter maior conhecimento, e o fundo obtém melhor relação entre retorno e o custo administrativo" (p. 16-17). "Os gestores também buscam oportunidades em setores que não possuem empresas dominantes e que permitam a consolidação. Setores altamente pulverizados talvez não se enquadrem nessa categoria. Estes setores passíveis de serem consolidados deverão apresentar empresas com potencial de liderança no setor, evidenciar possibilidade de crescimento, um determinado número de empresas que possam servir de benchmarking, contar com empresas-alvo disponíveis e que preencham qualificações mínimas em termos de baixa informalidade, tamanho mínimo e administradores que possam tocar o negócio" (p. 162).

88. Essa é uma indústria que trabalha, em seu centro vital, com a lógica da concentração econômica, quer adquirindo as empresas dominantes ou tornando as adquiridas, por uma série de rodadas de aquisições, dominantes. A isso dá-se, como se viu, o nome de "consolidação", que, em linguagem concorrencial, pode vir a ser qualificado como "concentração do poder econômico".

\section{ii. Controle das atividades das investidas como fator gerador de valor ("sinergia entre os diversos negócios" e "características concorrenciais dos planos de negócio"): prática concorrencialmente sensível}

89. Faz parte da organização da indústria, também, controlar, com o máximo de cuidado e acuro, os caminhos de seus investimentos, levando a diversas consequências que podem ser concorrencialmente sensíveis. Um primeiro ponto a ser levado em conta é a chamada "sinergia entre os diversos negócios" e a participação dos investidores em investidas-concorrentes, prática na qual as variáveis concorrenciais postam-se no centro da análise do investimento, inclusive com definições de mercado relevante geográfico e de produto.

90. Essa é uma lógica intrínseca da atividade, que traz tendencialmente questões concorrenciais a serem objeto de preocupação da autoridade, principalmente pelo que a literatura de "agente $\times$ principal" classifica como (i) "behind the scenes" 35 ou (ii) o poder de barganha do investidor de longo

35 GILLAN Stuart; STARK,S Laura. The evolution of shareholder activism in the United States. Journal of Applied Corporate Finance, v. 19, n. 1, p. 55, 2007. "The 1980s, by contrast, saw an increase in the involvement of institutional investors, at first mainly public pension. These pension funds submitted shareholder proposals, pressured management 'behind the scenes' for corporate reforms, and used the press to target the management and boards of poorly governed or performing companies." Esse movimento, no entanto, também possui sua própria historicidade, com se vê entre as p. 55 e 73: "In the early 1900s, American financial institutions such as insurance companies, mutual funds, 
prazo (quando passa a ser mais vantajoso seguir as orientações do investidor, para garantir a segunda ou terceira rodadas de investimentos, do que seguir o rumo normal do negócio; em países como o Brasil, no qual a indústria conta com alguns poucos investidores institucionais de peso gigantesco, esse pode ser um comportamento perfeitamente racional, ainda que distante do que a regulação determina).

\section{SINERGIAS POSSÍVEIS ENTRE DIVERSOS NEGÓCIOS}

(...) um fundo com recursos poderá contar com gestores e especialistas em seus quadros capazes de avaliar corretamente as empresas-alvo, desenvolver estratégias de crescimento e criar sinergias possíveis entre os diversos negócios. Este tipo de investidor costuma ter participação ativa no conselho das empresas investidas, pois os gestores do fundo têm uma visão ampliada das tendências dos mercados de atuação. (p. 23)

Os fundos de pensão, por outro lado, apresentam um interesse maior em ativos operacionais e em investimentos que permitam atuar na gestão. No Brasil, os maiores são de empresas estatais e estão aumentando suas participações em investimentos PE. Para ilustrar como esses agentes econômicos podem estimular os investimentos em PE, a CPFL Energia, holding de empresas do segmento, tinha, em 2009, seu capital repartido em 8,4\% da BNDESPar; 12,7\% da Bonaire Participações (Cesp, Petros, Sistel e Sabesprev); 31,1\% da Previ; e 25,7\% da VBC Energia (Holding controlada pela Camargo Corrêa, após a compra da participação da Votorantim). Assim, os Fundos de Pensão detinham 43,8\% da empresa. Por outro lado, a Previ também detinha $45,7 \%$, juntamente com a espanhola Iberdrola, da concorrente Neoenergia. A participação da Previ em duas das maiores empresas do segmento demonstra o quanto este tipo de investidor é importante para fomentar investimentos. (p. 25)

Os investimentos podem ser anexados em uma holding controlada pelo fundo ou simplesmente incorporados na empresa-alvo que iniciou o processo

and Banks were active participants in U.S. corporate governance. In many cases, the representatives of such institutions - among them J.P Morgan and his associates - served in corporate boards and played major roles in the strategic direction of the firm. [...] But with the decline of the take over market during the 1990s, and regulatory changes that enhanced the ability of shareholders to communicate on voting issues, activist institutional investors again came on the fore. At the same time, labor union pension funds began to assume a major role in investor activism. [...] While these different varieties of activism can still be seen today, the evolutionary process continues. In particular, hedge funds and private equity funds have assumed prominence in the activism arena. These funds have become increasingly important players in financial markets, particularly in their capacity as monitors of corporate performance and agents of change." 
de consolidação. Optando-se pela primeira alternativa, o fundo poderá deter uma visão consolidada das empresas e estimular a busca de sinergias entre essas. Um exemplo dessa estratégia é a holding internacional do segmento de varejo de alimentação OIMC, do Advent International, que controla empresas do segmento como Frango Assado, Rede Graal e Lago Azul, de postos e restaurantes; RA, restaurantes em aeroportos; Viena, restaurantes em shoppings e independentes; Brunella, dentre outros, que pode obter sinergias compartilhando centrais de armazenamento e pré-preparo de produtos, e treinamento de funcionários, além de obter maior escala e eficiência em compras. Adicionalmente, a holding pode estimular a formação de parcerias com empresas de outros setores, como varejistas, bancos e prestadores de serviços, para explorar o espaço físico de diversos pontos comerciais das empresas. (p. 183)

Enquanto vendedores consideram o fluxo de empresa de forma isolada, os investidores projetam os fluxos de caixa considerando eventuais sinergias com outros negócios. Pode-se afirmar, na maioria dos casos, que estes consideram fluxos de caixa diferentes e determinam valores distintos para a compra e para a venda. (p. 44)

As principais razões para os analistas negarem projetos nesta fase são os documentos de apresentação estarem desestruturados; as linhas de negócio serem desalinhadas com a estratégia do fundo em termos de segmentação, grau de controle, fase de desenvolvimento da empresa; o destino dos recursos a serem aportados não ser condizente com a estratégia dos fundos; e, principalmente, a falta de capacidade dos administradores da empresa-alvo. (p. 53)

A partir da definição da necessidade que gerou a intenção de aquisição, os estruturadores auxiliam os compradores na identificação das empresas mais adequadas em termos de perfil, possibilidades de sinergia e valor estimado do negócio. Atuam para entender os objetivos estratégicos que devem ser especificados, dentre os quais podem ser citados a obtenção de ganhos de escala, a necessidade de alianças estratégicas, as aquisições para entrada em novos mercados, o aumento da carteira de produtos, o acesso a canais de distribuição e todos os demais fatores que podem justificar uma aquisição. (...) Identificada a necessidade estratégica, o estruturador deverá estudar a cadeia produtiva que contém as empresas capazes de atender os objetivos do investidor. A prospecção dos projetos pode se originar internamente pelo gestor ou externamente, através do recebimento dos IM e dos PN. Na primeira alternativa, o fundo desenvolve antecipadamente uma estratégia de prospecção e, posteriormente, executa a mesma. Esta estratégia pode estar vinculada a uma oportunidade específica ou ao interesse do gestor em obter 
ganhos excepcionais através de possíveis sinergias entre empresas de um determinado segmento. (p. 54)

O vendedor de um ativo pode não considerar os objetivos estratégicos do comprador em suas análises, como, por exemplo, o quanto de valor será gerado em decorrência das sinergias resultantes de futuras aquisições. (p. 132)

91. Por outro lado, questões concorrencialmente sensíveis também estruturam os próprios "planos de negócio", que dão sustentação aos investimentos a serem realizados. Em tais "planos de negócio", a variável concorrencial é, sempre, central. Aqui, a hipótese muitas vezes aventada de "investimento meramente financeiro", que se apresenta como uma caricatura segundo a qual o "investidor coloca o dinheiro, e o esquece, voltando anos depois", deixa de guardar aderência com a realidade da estruturação concreta e real dos investimentos. A análise dos investimentos parte de seu elemento mínimo, como é óbvio, o "plano de negócios" da investida, que, sempre, apresenta as variáveis concorrenciais em seu centro, como não poderia deixar de ser.

\section{PLANOS DE NEGÓCIO DAS INVESTIDAS ESTRUTURAM-SE A PARTIR DE VARIÁVEIS CONCORRENCIALMENTE SENSÍVEIS}

Razões estratégicas para uma aquisição: 1.1. Aumentar o poder de mercado (...); 1.2. Ultrapassar barreiras de entrada (...); 1.3. Reduzir o custo de desenvolvimento de produtos (...); 1.4. Aumentar a velocidade de entrada no mercado $(. .) ;$.1.5 . Evitar a competição excessiva $(. .) ;$.1.6 . Obter ganhos de escala (...). (p. 28-31)

O plano de marketing é composto da análise de mercado, descrição dos produtos e serviços e da estratégia de comunicação. Análise de mercado: A análise de mercado é composta da coleta de dados, identificação da estrutura do mercado e determinação das tendências; do diagnóstico da concorrência; do posicionamento da empresa; e da análise dos clientes. A identificação da estrutura do mercado parte da determinação do tamanho do mesmo no passado, presente e potencial futuro. (...) Na determinação da estrutura do mercado, busca-se descrever os diferentes modelos de negócio existentes e o grau de competição da indústria. Para se avaliar o grau de competitividade dos concorrentes, determina-se a participação de mercado dos concorrentes individualmente e obtém-se informações relevantes dos mesmos em termos de dados relacionados à performance como faturamento, volume das vendas físicas, resultados operacionais, endividamento e dados operacionais, como funcionários, dentre outros. Idealmente, contribui para a análise da provável estratégia da concorrência a descrição dos seus pontos fortes e fracos. A 
segmentação dos clientes é a base para a estratégia de precificação. (...) as empresas devem ter uma visão clara de quais são seus fornecedores de produtos substitutos, novos entrantes e clientes, através da descrição da cadeia produtiva. (...) Abordam-se nos $\mathrm{PN}$ os diferenciais em relação à concorrência e, no caso de novos produtos ou mercado, as etapas de lançamento dos mesmos. (...) O resultado destas análises permitirá ao elaborador ou avaliador do plano de negócios estimar os direcionadores que geram as entradas do fluxo de caixa. As informações permitem prever o volume de vendas e serviços em termos operacionais e apresentá-los em termos financeiros. As entradas do fluxo poderão descritas em termos de receitas, mas deve-se ressaltar que todas as análises são conduzidas em regime de caixa. Utilizam-se dados contábeis quando os dados financeiros em termos de caixa não estão disponíveis ou quando o tempo se encarrega de equivaler os dois tipos de registro. Todas as planilhas são elaboradas a partir dos resultados operacionais esperados e são interligadas, sendo que a planilha que contém as análises do plano de mercado se interliga com as demais, principalmente a do plano operacional, e o resultado deste relacionamento é quantificado no plano financeiro. (p. 69-72) ${ }^{36}$

36 “O Plano de Negócios começa com a definição de um objetivo estratégico e, para isso, é necessário responder a algumas perguntas: [1.] Quem é seu cliente? Definem-se os critérios de segmentação e quantifica-se o potencial da receita. A melhor forma de segmentar dependerá do tipo de negócio, da estrutura da empresa e das características gerais do mercado. (...) [2] Qual o tamanho do mercado? A partir da segmentação, que permite inferir sobre qual é o mercado da empresa em termos potenciais, tornam-se necessárias a quantificação do mesmo e a realização das estimativas de entrada de caixa futuras. (...) Assim, aplicam-se percentuais de market share esperado sobre o tamanho do mercado total projetado. [3] Quais os pontos fortes e fracos da empresa? Apresentar os fatores que geram vantagens competitivas e como as oportunidades podem ser exploradas permitem ao empreendedor tornar o seu projeto mais interessante para o investidor. Assim, qualquer iniciativa será comentada em termos de diferenciais em relação aos concorrentes, de suas estratégias de marketing para gerar valor, dos passos para que se consigam desenvolver competências, como, por exemplo, formação de alianças, necessidade de terceirização, dentre outras. A análise da concorrência não deve ser conduzida de forma apenas quantitativa, mas, para que esta análise seja também completa, devem-se avaliar o posicionamento e os fatores que direcionam os concorrentes. [4] Qual o principal objetivo estratégico? Os PN devem deixar claro quais são os principais objetivos estratégicos da empresa ou do projeto em termos de poder de mercado; estabelecimento de posição defensiva; entrada em novos segmentos; obtenção e redução de custo, ampliação da carteira de produtos; e uso de novas tecnologias ou processos." (p. 63-66) As variáveis concorrencialmente sensíveis dividem-se também funcionalmente, como na análise concorrencial, entre mercados relevantes quanto ao produto e quanto à geografia: "Relatórios bem elaborados deverão ser capazes de identificar e apresentar as vantagens competitivas da iniciativa, ou seja, os diferenciais em relação à concorrência e o que fará com que a empresa se posicione no mercado" (p. 82); "Analisam-se o mercado de atuação da empresa, a região em que a empresa atua; (...)." (p. 55); "(...) primeiramente, realiza-se a identificação das oportunidades estratégicas e dos mercados de interesse. Posteriormente, realiza-se o mapeamento do mercado com o objetivo de selecionar as empresas participantes 
92. Esse cuidado obrigatório com as questões concorrenciais contidas no Plano de Negócios das investidas coloca um grau de dúvida em relação às manifestações sobre "investimentos meramente financeiros", como afirmado, principalmente quando se sabe que, na realidade da indústria em questão, "o resultado do fundo é monitorado pelos executivos em reuniões periódicas quando se discutem os resultados individuais das empresas-alvo. $\mathrm{O}$ orçamento anual dessas empresas é comparado com o realizado, bem como com a gestão do caixa, e dessa forma pode-se alterar a estratégia da empresaalvo ou mesmo a administração. Torna-se necessário que este processo, o qual envolve diagnosticar a situação e atuar para reposicionar a empresa, seja frequente e eficaz visando a maior rentabilidade do fundo. Empresas em setores mais estáveis costumam apresentar menos risco, ou volatilidade de retornos, do que empresas em segmentos relacionados a inovação. Os riscos desses investimentos diferem por natureza e, por isso, podem-se esperar retornos compatíveis. Por esta razão, a análise contábil permitirá avaliar o desempenho do exercício, mas somente a análise por fluxo de caixa descontado permitirá apresentar o quanto foi gerado de valor na empresa, por considerar a perspectiva de crescimento da empresa e o risco do fluxo de caixa gerado". (p. 160) $)^{37}$

\section{iii. Proximidade intensa entre os diversos atores como fator gerador de valor: prática concorrencialmente sensível}

93. A atividade em análise tem como um insumo de alto valor a informação, em suas variadas manifestações. É por isso que saídas formalistas se

da cadeia produtiva com potencial de se tornarem alvos para aquisição. As fases seguintes são a avaliação das empresas-alvo, processo que demandará contatos com os representantes dos sócios das empresas a serem vendidas ou seus consultores, a negociação final, e a auditoria da empresa e das premissas dos documentos apresentados pelos vendedores" (p. 43).

37 Essa caricatura do "investimento meramente financeiro", que entregaria o dinheiro e só voltaria para pegar o resultado, também se afasta quando se está diante de dinâmicas nas quais os fundos passam a controlar diretamente a atividade produtiva, como em um dos tantos exemplos existentes, noticiado pelo jornal Valor Econômico de 23, 24 e 25 de março de 2012: "Após a captação de fundos bilionários dedicados a aquisições de empresas no país nos últimos anos, as gestoras de private equity partem para a especialização. A Gávea Investimentos, fundada pelo ex-presidente do Banco Central Armínio Fraga, prepara a criação de uma área com foco no setor imobiliário. (...) Não se trata da primeira incursão no setor da Gávea, que já investiu em companhias como a Odebrecht Realizações Imobiliárias e a Aliance Shopping Centers, por meio do braço de private equity. Mas a intenção agora é investir diretamente em empreendimentos imobiliários, em vez de comprar participações acionárias em companhias. (...) O braço imobiliário da GP Investimentos está em processo de captação de um novo fundo. O BTG Pactual partiu diretamente para aquisições de empresas que já detém ou fazem gestão de ativos, entre elas a WTorre e a Brazilian Capital, de onde veio o executivo que agora se junta à Gávea". 
apresentam tão frágeis, caso se esteja diante de problemas sérios. Essa proximidade intensa entre os diversos atores da indústria não raro leva à troca de papéis, portando consigo, aquele que mudou de posições, por óbvio, o bem intangível que é a informação.

94. A aparência de separação, de muralhas chinesas, ou a assinatura de instrumentos legais aparentemente mais ou menos preocupados com este fato, não necessariamente resolvem problemas concorrencialmente intensos, pela própria estrutura da indústria, principalmente quando a passagem se dá daquele que aparentava ser "investidor meramente financeiro" para "declarado investidor estratégico": "O mercado de investimento de capital de risco pode ser entendido a partir de cinco classe de participantes: (1) a dos investidores, aqueles que alocam recursos fornecendo o funding, sendo estes profissionais ou estratégicos; (2) a dos gestores, envolvidos diretamente na gestão da carteira, como os fundos, os bancos de investimento e as gestoras de ativos, assets; (3) a dos estruturadores, consultorias ou casas de M\&A, que contribuem para a estruturação do negócio; (4) a das empresas-alvo, ou seja, os ativos que comporão as carteiras dos investidores; e (5) a dos empreendedores, sócios ou acionistas das empresas adquiridas. (...) A distinção entre essas categorias é tênue, pois um gestor, por exemplo, banco de investimento, pode ser investidor em outro, um fundo de private equity, e pode atuar, simultaneamente, como estruturador" (p. 13-14). "Investidores financeiros são aqueles que essencialmente não atuam diretamente no segmento da empresa-alvo, mas consideram o seu segmento de atuação como potencialmente atrativo. Após a entrada no segmento, este tipo de investidor pode se transformar em investidor estratégico, caso exista a possibilidade de se obterem ganhos operacionais ou estratégicos. Especificamente, o private equity em sua essência está voltado para a obtenção de maior eficiência operacional e financeira nas empresas investidas. Existem motivos estratégicos e financeiros para um investidor fazer aquisições que estão relacionadas com interesses dos comprador, dos vendedores ou necessidades das próprias empresas-alvo. Estas podem carecer de reestruturação para se tornarem novamente competitivas ou necessitarem de recursos para investimentos destinados a fornecê-las através de aquisições ou crescimento orgânico. Uma razão usual para a aquisição por um fundo de PE é a possibilidade de consolidar a indústria. As possibilidades para os investidores obterem ganhos superiores ao comprar uma empresa são pequenas se um desses motivos não estiver sendo considerado. Por outro lado, perseguindo um desses objetivos, os investidores poderão obter retornos maiores. Mesmo os investidores financeiros acabam executando objetivos 


\section{estratégicos para maximizar os ganhos, pois, após haverem fornecidos recursos para os investimentos, estes serão utilizados para o crescimento orgânico ou para aquisições" (p. 15)..$^{38}$}

\section{iv. Não Apresentação de Operações ao SBDC: prática concorrencialmente sensível}

95. Os dados existentes a respeito da quantidade de operações realizadas pela indústria e o número de operações apresentadas ao SBDC parecem, à primeira vista, não coincidir. Se tal fato, depois de realizado um estudo pelo Departamento de Estudos Econômicos do Cade, vier a ser confirmado, devem ser questionadas as causas e tomadas as medidas necessárias à eficácia social da lei de defesa da concorrência. ${ }^{39}$

38 Essa fluidez de posições que pode se tornar concorrencialmente sensível é passível de ocorrer em diversas direções: "Alguns fundos independentes estão se associando a bancos de investimentos para investir na modalidade private equity. Neste caso, os fundos entram com know how de gestão e os bancos aportam recursos e, em alguns casos, contribuem com a atração de empresas-alvo devido a sua capilaridade" (p. 36). "Os outros fundos também são geradores de negócio, principalmente naqueles em que as operações possam ser sindicalizadas devido ao montante envolvido ou perfil de risco. Os bancos de investimento associados a bancos comerciais se beneficiam da rede de relacionamento destes últimos" (p. 55). Essa miríade de papéis pode trazer um custo de transação interno aos investidores também, inclusive quando são investidores institucionais com participações em diversas companhias, como ilustra o caso narrado pelo jornal Valor Econômico, em 25-26-27 de maio de 2012, A12: "Fundo é três vezes maior que o $2^{\circ}$ do ranking. A Caixa e Previdência dos Funcionários do Banco do Brasil não é um simples fundo de pensão, mas um animal diferente dos outros de sua espécie. Primeiro, pelo porte. Com mais de $\mathrm{R} \$ 155$ bilhões em patrimônio, é quase três vezes maior que a Petros, dos funcionários da Petrobras, a segunda maior fundação do país, com R\$ 58 bilhões. Mas, além de muito maior, esse patrimônio está distribuído de maneira diferente. A participação de renda variável na carteira do Plano 1, onde estão mais de $98 \%$ dos ativos geridos pela Previ, é de $64 \%$, muito acima de qualquer outro plano de previdência maduro. Na Petros, por exemplo, essa fatia é de $37 \%$ do total. Com uma carteira de ações tão grande, a Previ tem que tomar cuidado ao mexer na bolsa, mesmo com a parcela de sua carteira destinada a giro, para não afetar os preços de forma a que prejudique sua própria estratégia. Entre as participações relevantes que possui e nas quais atua diretamente na gestão, estão Vale, Embraer e Neoenergia".

39 "Segundo a empresa de consultoria PWC, PricewaterhouseCoopers (2008), em seu relatório sobre o setor de private equity \& venture capital, o ano de 2007 registrou um volume recorde de 718 transações de empresas divulgadas na imprensa, com crescimento de $25 \%$ em relação ao ano anterior. Os Fundos PE estiveram presentes em 14\% das transações, o que corresponde a 100 transações neste ano, contra 10\% no ano anterior. Ainda segundo esta empresa, o volume de operações de PE cresceu 25\% em relação a 2006. A PWC afirma que as operações no Brasil apresentavam a característica de serem multissetoriais, ou seja, evidenciadas em diversos setores da economia. Nos anos de 2006 e 2007, destacaram-se os setores de construção, alimentos e bens de consumo (duráveis e não duráveis), tecnologia, educação, varejo, financeiro e mineração. Observou-se, no primeiro semestre de 2008, investimento nos setores de saúde, prestação de serviços, agronegócios e infraestrutura. Segundo relatório da FGV, Fundação Getulio Vargas, que estudou o mercado brasileiro de PE de 1999 a 2004, o total de operações em 2004 atingiu US\$ 5,5 bilhões, nas 300 empresas analisadas que captaram recursos das 71 


\section{Atuação do Estado sobre a economia dos fundos de investimento - nova lei, nova resolução}

96. A nova lei de concorrência, pelo fato de introduzir a análise prévia, com consequências sobre a consideração de eficácia negocial, acopladas a reorganização administrativa, provavelmente mudará o quadro de atuação do Cade quanto aos fundos.

97. De início, ressalte-se a necessidade que este Conselho tem para a definição do sentido dos artigos 88 e 90: "Art. 90. Para os efeitos do art. 88 desta Lei, realiza-se um ato de concentração quando: I - 2 (duas) ou mais empresas anteriormente independentes se fundem; II - 1 (uma) ou mais empresas adquirem, direta ou indiretamente, por compra ou permuta de ações, quotas, títulos ou valores mobiliários conversíveis em ações, ou ativos, tangíveis ou intangíveis, por via contratual ou por qualquer outro meio ou forma, o controle ou partes de uma ou outras empresas; III - 1 (uma) ou mais empresas incorporam outra ou outras empresas; ou IV -2 (duas) ou mais empresas celebram contrato associativo, consórcio ou joint venture".

98. Assim, logo no primeiro dia de vigência da nova Lei, foram expedidas diretrizes, por meio de Resolução no 2, que responde às principais questões a respeito de quem e em que condições deve notificar suas operações: "Art. $4^{\circ}$ Entende-se como partes da operação as entidades diretamente envolvidas no negócio jurídico sendo notificado e os respectivos grupos econômicos. $\S 1$ ㅇ. Considera-se grupo econômico, para fins de cálculo dos faturamentos constantes do art. 88 da Lei 12.529/11 e do preenchimento dos Anexos I e II dessa Resolução, cumulativamente: I - as empresas que estejam sob controle comum, interno ou externo; $\mathrm{eII}$ - as empresas nas quais qualquer das empresas do inciso I seja titular, direta ou indiretamente, de pelo menos $20 \%$ (vinte por cento) do capital social ou votante. $\S 2$ o No caso dos fundos de investimento, são considerados integrantes do mesmo grupo econômico, cumulativamente: I - os fundos que estejam sob a mesma gestão; II - o gestor; III — os cotistas que detenham direta ou indiretamente mais de $20 \%$ das cotas de pelo menos um dos fundos do inciso I; e IV - as empresas integrantes do portfolio dos fundos em que a participação direta ou indiretamente detida pelo fundo seja igual ou superior a $20 \%$ (vinte por cento) do capital social ou votante. (...) Art. 9o As aquisições de participação societária de que trata o artigo 90, II,

empresas gestoras contatadas pelos pesquisadores. Em 1999, apenas 100 empresas captavam recursos nessa modalidade. Destas, $70 \%$ da amostra estavam localizadas na região sudeste." (p. 12) 
da Lei 12.529/2011 são de notificação obrigatória, nos termos do art. 88 da mesma lei, quando: I - Acarretem aquisição de controle; II - Não acarretem aquisição de controle, mas preencham as regras de minimis do artigo 10; ou III - Sejam realizadas pelo controlador, na hipótese disciplinada no artigo 11. Art. 10 Nos termos do artigo 9, II, são de notificação obrigatória ao Cade as aquisições de parte de empresa ou empresas que confiram ao adquirente o status de maior investidor individual, ou que se enquadrem em uma das seguintes hipóteses: I - Nos casos em que a empresa investida não seja concorrente nem atue em mercado verticalmente relacionado: a) Aquisição que confira ao adquirente titularidade direta ou indireta de $20 \%$ (vinte por cento) ou mais do capital social ou votante da empresa investida; b) Aquisição feita por titular de $20 \%$ (vinte por cento) ou mais do capital social ou votante, desde que a participação direta ou indiretamente adquirida, de pelo menos um vendedor considerado individualmente, chegue a ser igual ou superior a $20 \%$ (vinte por cento) do capital social ou votante. II - Nos casos em que a empresa investida seja concorrente ou atue em mercado verticalmente relacionado: a) Aquisição que conferir participação direta ou indireta de 5\% (cinco por cento) ou mais do capital votante ou social; b) Última aquisição que, individualmente ou somada com outras, resulte em um aumento de participação maior ou igual a 5\%, nos casos em que a investidora já detenha $5 \%$ ou mais do capital votante ou social da adquirida".

\section{J. Desafios à atuação do Cade no novo contexto: a gestão da informação e do tempo}

99. A expedição dessa regulamentação administrativa tem a pretensão de resolver a maioria das questões referentes ao conhecimento ou não.

100. Isso trará alguns desafios, que obrigará a um deslocamento da atuação do órgão, devendo, provavelmente, envolver os seguintes aspectos: (i) a quantidade de operações a ser notificada aumentará, com alta probabilidade; (ii) quais informações devem ser extraídas dos requerentes; (iii) como armazenar e dar coerência sistêmica às informações, para apreender o movimento total da economia dos fundos de investimento, seu impacto setor a setor e na própria economia brasileira como um todo; (iv) como identificar e dar correto tratamento às questões concorrencialmente sensíveis (das quais as quatro acima apresentadas são apenas parte do quadro geral); (v) como realizar as análises em tempo adequado, que simultaneamente conforte a busca de uma concorrência saudável e a conclusão dos negócios; (vi) como articular-se às demais agências e órgãos governamentais competentes em suas 
específicas áreas (dando, por exemplo, eficácia ao artigo 88, Parágrafo 8o, da Lei 12.529/2011: "As mudanças de controle acionário de companhias abertas e os registros de fusão, sem prejuízo da obrigação das partes envolvidas, devem ser comunicados ao Cade pela Comissão de Valores Mobiliários - CVM e pelo Departamento Nacional do Registro do Comércio do Ministério do Desenvolvimento, Indústria e Comércio Exterior, respectivamente, no prazo de 5 (cinco) dias úteis para, se for o caso, ser examinados".).

101. Esses são desafios de organização interna e externa, que, a meu ver, trazem uma nova fase da atuação do Cade sobre a economia dos fundos de investimento, menos focado nas questões formais sobre conhecimento ou não, e mais vertido à estruturação institucional para a verificação material setor a setor da economia.

102. Do ponto de vista dos envolvidos em operações, certamente a questão do tempo avulta em importância.

103. Sabe-se que uma venda "rápida" chega a durar nove meses (cf. Rossi, op. cit., p. 45: “Na indústria de VC e PE, os papéis são definidos e existe um roteiro de passos para que as negociações sejam concluídas, e, para termos uma melhor compreensão da duração destas ações, exemplificaremos com prazos de um processo de sell side considerado rápido. Pode-se demorar um mês para escolher os estruturadores e assinar os mandatos de compra e venda; outros dois meses para se preparar o IM; a busca de investidores, apresentações e negociação com os alvos podem acontecer em três meses adicionais; sendo necessários três meses adicionais para a conclusão, que inclui a due diligence, ou seja, uma venda rápida pode ser executada em nove meses".). Operações mais trabalhosas podem levar anos para serem concretizadas (cf. Rossi, op. cit., p. 131: “O processo de negociação em VC e PE costuma não ser rápido, podendo estimar que a maioria dos negócios apresenta prazo mínimo de seis, sendo comum alguns perdurarem por anos".).

104. Assim, será um desafio do Cade buscar, resguardando a defesa da concorrência, também um tempo razoável para os que apresentarão operações.

105. Tal desafio será mais bem-sucedido, é claro, se ocorrer um diálogo com as associações representativas. A ABVCAP - Associação Brasileira de Private Equity e Venture Capital, por exemplo, tem procurado o Conselho com o fim de construção de uma agenda para essa nova fase, "a fim de permitir que os agentes de mercado contribuam de forma mais significativa e eficiente com as atividades de supervisão da livre concorrência pelo Cade, incluindo-se (...) o auxílio da ABVCAP no acompanhamento pelo Cade de transações envolvendo fundos de investimentos [e] a elaboração de análises 
e de estudos sobre a concorrência na indústria de fundos de investimentos" (correspondência de abril de 2012).

106. Essas todas são questões gerais que permeiam, mas certamente transcendem, a operação em análise, podendo ser objeto de reflexão do Conselho para o futuro que já se faz presente com a vigência da Lei 12.529/2011.

\section{Do Mérito}

107. A presente operação estrutura a aquisição, pelo Fundo Rio Bravo, de participação equivalente a 50\% do capital social e votante de SPE a ser constituída para a implantação, desenvolvimento e operação do projeto de geração eólica denominado CGE Malhadinha I. Os outros 50\% da SPE serão detidos pela Servtec.

108. Para fins da implantação e da exploração do projeto, será criada uma SPE (i) para a qual todos os ativos, direitos e licenças relacionados à CGE Malhadinha I serão transferidos, e (ii) que receberá as outorgas para a produção e venda da energia adjudicadas no Leilão. A CGE Malhadinha I foi cadastrada na Empresa de Pesquisa Energética - EPE para participar do Leilão A-3/Reserva de 2011. A inscrição no Leilão foi feita em nome do consórcio constituído pela Servtec com duas de suas sociedades controladas (Servtec Energia Ltda. e Servtec RM Participações S.A.).

109. A aquisição de participação por parte do Fundo Rio Bravo se dará, alternativamente: (i) por meio da subscrição e integralização de debêntures conversíveis, com posterior conversão desses títulos em ações de emissão da SPE; ou (ii) por meio da subscrição e integralização de ações ordinárias de emissão da SPE.

110. A Seae se pronunciou da seguinte maneira (fls. 39): "A presente operação trata do investimento financeiro a ser realizado pelo Fundo Rio Bravo em sociedade de propósito específico ('SPE') a ser constituída para a implantação, desenvolvimento e operação de empreendimento de geração de energia de fonte eólica no Brasil. 4. Setor/Atividade Econômica Afetada: Geração de energia elétrica pela matriz eólica. (...) O Fundo Rio Bravo é um fundo de investimento em participações cujo objetivo é a realização de investimentos em projetos de geração de energia elétrica no Brasil, com ênfase em energias renováveis, podendo, também, realizar investimentos em ativos de transmissão e geração de energia de fonte não renovável. A Servtec é uma empresa pertencente ao Grupo Servtec, grupo este que atua nas áreas de 
energia e engenharia em empreendimentos. No setor energético, atua na idealização, desenvolvimento de projetos conceituais e executivos, investimento, implantação e operação de usinas de geração de energia elétrica por fontes renováveis como, a eólica e a hídrica, e de geração através de energia térmica (a óleo e gás natural). Na área de engenharia, idealiza soluções específicas para as necessidades de cada um de seus clientes e aplica seu know-how em todas as fases dos empreendimentos que capitaneia. (...) o presente ato de concentração não implica alteração da composição do capital social das requerentes, mas na constituição de um novo projeto de geração eólico denominado CGE Malhadinha I, com capacidade produtiva de $24.000 \mathrm{~kW} / \mathrm{ano}$, a ser implantado na cidade de Ibiapina/CE. Os ativos, direitos e licenças relacionadas aos projetos acima são atualmente detidos integralmente pela Servtec e foram cadastrados para participar do Leilão A-3/Reserva de 2011, conforme Portaria no 113/2011, do Ministério de Minas e Energia (MME), alterada pelas Portarias no 160/2011 e no 262/2011. A inscrição no leilão, segundo as requerentes, foi feita em nome de consórcio constituído pela Servtec com duas de suas sociedades controladas; porém, o Fundo Rio Bravo passou a fazer parte do consórcio antes de sua fase construção. Portanto, com base nas informações acima mencionadas, conclui-se que operação notificada não ocasiona sobreposição horizontal ou integração vertical entre as atividades das requerentes, uma vez que ela representa a implantação de um consórcio que está inserido no Ambiente de Contratação Regulada (ACR), regulado pela Agência Nacional de Energia Elétrica (Aneel). Dessa forma, o consórcio representaria um acréscimo na capacidade instalada de geração de energia elétrica pela matriz eólica, cuja concorrência deu-se previamente no leilão realizado pelo MME. (...) 7. Recomendação: Aprovação sem restrições".

111. A Procade manifestou-se nos seguintes termos (fls. 278): "Analisandose o Acordo de Investiment e outras, verifica-se que [CONFIDENCIAL]. Por outro lado, nos termos do item 14.5 do Edital de Leilão 03/2011, A-3, quando a vendedora tiver concorrido em consórcio, a SPE deverá ser constituída apenas pelas consorciadas. Desse modo, no presente caso, a sociedade de propósito específico apenas haverá de ser constituída pelas empresas do Grupo Servtec, acima referidas, vez que únicas partícipes do consórcio habilitado e vencedor do leilão. A constituição da SPE pelas empresas do grupo Servtec constitui ato realizado por empresas dependentes, não se sujeitando à notificação. Sendo assim, resta analisar o aporte do Fundo Rio Bravo na SPE. Nos termos do acordo de investimento referido, o Fundo Rio Bravo, mediante o cumprimento de determinadas condições, tem o interesse de investir no 
empreendimento elétrico, seja: (i) por meio de subscrição e integralização de debêntures conversíveis de emissão da SPE; ou (ii) através da subscrição e integralização de ações ordinárias de emissão da SPE em quantidade que assegure ao FIP participação equivalente a 50\% no capital da social da SPE. Tal aquisição de ações/debêntures conversíveis é que constitui a operação ora notificada. [Dos efeitos da presente operação para a concorrência] De um modo geral, em relação aos efeitos da operação sobre a concorrência, importaria salientar alguns pontos que poderiam constituir objeto de análise de concentração envolvendo FIPs. A análise também deve considerar se a empresa gestora do fundo também gere outros fundos com investimentos em empresas rivais, tendo em vista que, nesse caso, as estratégias de investimento partirão de um mesmo centro decisório. Por fim, deve-se examinar as relações horizontais e verticais entre a empresa-alvo e as empresas nas quais o fundo detenha participação, majoritária ou influência relevante, bem como aquelas empresas rivais em que sua participação seja minoritária. No presente caso, os pontos de análise acima referidos poderiam ser considerados nesse momento, todavia convém, desde já, referir que o empreendimento eólico que será explorado pela SPE constituída apresentará participação muito pequena no parque de geração de energia elétrica do Sistema Interligado Nacional - SIN, considerando o percentual de potência gerada atribuída a empreendimentos eólicos (EOL), conforme quadro [de elaboração da Aneel]. Por outro lado, não se verifica a possibilidade de eventuais efeitos nocivos à concorrência decorrentes da relação horizontal entre a SPE e a empresa na qual o fundo requerente possui participação, a RBO Energia S.A. (...) a empresa RBO gera apenas [CONFIDENCIAL] kw/ano de energia elétrica, que equivale a [CONFIDENCIAL] da capacidade de geração do mercado nacional de geração de energia. Vale ressaltar que o mercado relevante no setor de energia elétrica não deve ser regionalizado, devendo ser considerado o mercado abrangido pelo Sistema Interligado Nacional - SIN, excluindo-se os Sistemas Isolados. Tampouco, na dimensão produto, o mercado relevante há de ser definido levando-se em conta o tipo de fonte energética. Saliente-se, ainda, que as informações a respeito da participação de mercado da empresa RBO foram obtidas no sítio eletrônico da Aneel e correspondem a um percentual meramente aproximado, vez que as informações da Agência Reguladora dizem respeito ao percentual de potência outorgada no Brasil, levandose em conta, inclusive, a potência dos Sistemas Isolados. Não obstante, no presente caso, a concentração de mercado não é expressiva, considerandose o percentual de participação da empresa RBO Energia S.A. na geração de 
energia no SIN. (...) Quanto à operação ora notificada, recomenda-se o seu conhecimento e, no mérito, sua aprovação sem restrição".

112. Mesmo com os dois pareceres favoráveis, impende retratar ainda que meu gabinete realizou atividade instrutória por meio dos ofícios de fls. 47 (solicitando "apresentação do regulamento de Rio Bravo Energia I Fundo de Investimento em Participações"); fls. 115 (solicitando os seguintes esclarecimentos: "sobre a empresa Rio Bravo Investimentos Ltda. e a empresa Rio Bravo Project Finance Assessoria Empresarial Ltda., 'Administradora' e 'Assessor de Investimentos', respectivamente, do Fundo Rio Bravo Energia I informe, para cada uma delas: 2.1. Nome de acordo com o estatuto social, nome do representante legal, CNPJ/MF e inscrição estadual; Setor de atividade; 2.3. Endereço, números de telefone e fax, e endereço de correio eletrônico; 2.4. Nomes dos acionistas ou quotistas com as respectivas participações no capital social, discriminando a natureza da participação societária; 2.5. Grupos dos quais fazem parte, indicando nacionalidade de origem; 2.6. Principal setor de atividade de cada grupo; 2.7. Relação de todas as empresas direta ou indiretamente componentes dos grupos, com atuação no Brasil e no Mercosul, bem como das empresas nas quais pelo menos uma das integrantes do grupo detenha participação social superior a 5\%, com atuação no Brasil e no Mercosul"); fls. 139 (solicitando "1.1. informar outras participações ou investimentos dos quotistas do Fundo Rio Bravo relacionados ao mercado de geração de energia. Deve-se, para a presente resposta, considerar qualquer forma de participação ou investimento, seja direta ou indiretamente, por meio de outros fundos de investimento ou não, dos quotistas. 1.2. considerando a resposta anterior, estimar a participação de mercado dos quotistas, individualmente e como um todo, no mercado relevante sob análise" ${ }^{\prime \prime}$ ); fls. 148 ("os seguintes esclarecimentos quanto às sociedades Verace Energia Eólica Ltda., Chuí Energia Eólica Ltda. e Minuano Energia Eólica Ltda. [...]: 1.1. Apresentar o quadro dos quotistas das sociedades mencionadas, indicando as respectivas participações no capital social; 1.2. Apresentar os Estatutos Sociais das sociedades acima mencionadas; e 1.3. Informar se houve alguma mudança no quadro societário das sociedades acima referidas quando da aquisição, pela Eletrosul, de seus respectivos direitos relativos a projetos de geração de energia elétrica sob matriz eólica [evento indicado no 'primeiro considerando' do acordo de investimentos]. Em caso afirmativo, informar a alteração"); fls. 249 ("1.1. Informe os nomes dos acionistas, com as respectivas participações no capital social, da Rio Bravo Investimentos S.A., indicada na resposta ao Ofício [...] como a principal quotista da Rio Bravo Investimentos 
Ltda., que, por sua vez, é a administradora e gestora do fundo Rio Bravo. 1.2. Informe todos os outros fundos de investimentos geridos e/ou administrados por qualquer sociedade relacionada ao que se convencionou de Grupo Rio Bravo. Deve-se incluir na resposta ao presente quesito qualquer outro fundo gerido e/ou administrado por sociedade na qual o Grupo Rio Bravo detém participação no capital social superior a 5\%"); fls. 268 (apresentação "[i] do Estatuto Social de Rio Bravo Investimentos S. A. e [ii] do Regulamento de Rio Bravo Investimentos - Fundo de Investimentos em Participações"); fls. 303 ("2.1. Informar a capacidade de geração de energia de matriz eólica existente atualmente; 2.2. Informar a capacidade de geração de energia de matriz eólica prevista para entrar em operação até dezembro de 2014; 2.3. Informar leilões de energia eólica previstos para os próximos dois anos, informando a capacidade de geração prevista a ser leiloada").

113. Essa atividade instrutória culminou com a concordância com as opiniões exaradas pelos outros dois órgãos. As respostas foram satisfatórias do ponto de vista concorrencial.

114. Assim, voto pela aprovação do ato sem restrições.

É o voto.

Brasília, 29 de maio de 2012.

\section{ALESSANDRO SERAFIN OCTAVIANI LUIS}

Conselheiro-Relator 